\title{
STATE ACTION AS A SHIELD AND A SWORD IN A MEDICAL SERVICES ANTITRUST CONTEXT: PARKER V. BROWN IN CONSTITUTIONAL PERSPECTIVE*
}

\author{
JAMES F. BLUMSTEIN** and TerRy CALVANI***
}

\section{INTRODUCTION}

Freshman economics teaches that freedom of entry into the market is a requisite to competition. Nevertheless, there are numerous barriers to entry in almost every industry directly engaged in the delivery of health care services. Many, if not most, of these barriers have been created or at least approved by local, state or federal government. That this governmental regulation reduces competition is not subject to serious dispute, but its proponents assert that consumer protection is the compensating value. Although the federal antitrust laws seek to insure the existence of competition in interstate commerce, the delivery of health care services has been subjected to the scrutiny of the antitrust laws only rarely.

The conventional wisdom has been that the provision of medical care was somehow different from other sectors of the economy. Emphasis on the differences between the delivery of medical services and the provision of other goods and services has had the effect of inhibiting consideration of many of the similarities between medical services and other economic goods and services. Underlying the paucity of legal activity was the assumption that the practice of medicine and its allied arts was a "learned profession" and thus not the "trade or commerce" required by the antitrust laws. ${ }^{1}$ The few antitrust cases brought

* Professor Blumstein's work was supported in part by the Vanderbilt Institute for Public Policy Studies. In the final stage, support also came from the Department of Community Medicine, Dartmouth Medical School.

** B.A., Yale College, 1966; M.A. Yale University, 1970; LL.B., Yale Law School, 1970. Professor of Law, Vanderbilt Law School; Senior Research Associate, Vanderbilt Institute for Public Policy Studies.

*** B.A., University of New Mexico, 1969; J.D., Cornell University, 1972. Associate Professor of Law, Vanderbilt Law School.

THE FOLLOWING CITATION WILL BE USED IN THIS ARTICLE:

L. TRIBE, AMerican Constitutional LAw (1978) [hereinafter cited as L. TRIBE].

1. See, e.g., Goldfarb v. Virginia State Bar, 497 F.2d 1, 13 (4th Cir. 1974), rev'd, 421 U.S. 773 (1975). 


\section{were either dismissed, or the issue was somehow avoided. ${ }^{2}$}

Recently, however, attention has been focused on the opportunities that may exist for the application of more traditional, market-oriented techniques to the medical marketplace as a tool for the effectuation of social policy objectives. Moreover, with the Supreme Court's recent decision in Goldfarb v. Virginia State Bar, ${ }^{3}$ holding that the "learned professions" are not exempt from the application of the antitrust laws, considerable interest in the application of antitrust principles to the delivery of health care can be expected. Indeed, there are already numerous manifestations of that interest in the courts and administrative agencies. ${ }^{4}$

2. The three most noteworthy cases were American Medical Ass'n v. United States, 317 U.S. 519 (1943); United States v. Oregon State Medical Soc'y, 95 F. Supp. 103 (D. Ore. 1950), affd, 343 U.S. 326 (1952); and Group Health Coop. v. King County Medical Soc'y, 39 Wash. 2d 586, 237 P.2d 737 (1951). In the $A M A$ case the government alleged that organized medicine had attempted to impede the organization and implementation of a group health plan for federal employees. Although the defendants strenuously argued that the Sherman Act did not apply to the practice of medicine since it could not be characterized as "trade," the Court avoided the issue, stating that "the calling or occupation of the individual physicians charged as defendants is immaterial if the purpose and effect of their conspiracy was such obstruction and restraint of the business of Group Health." 317 U.S. at 528. Group Health Cooperative was brought pursuant to the Washington state antitrust law, and the federal issue was thus avoided. Interestingly, the Washington Supreme Court held that the restraints on the practice of medicine were restraints of trade or commerce under the common law. 39 Wash. $2 \mathrm{~d}$ at 638,237 P.2d at 765. A different result-at least in the trial court-was obtained in Oregon State Medical Society. There the district court held that the maintenance of a prepaid health care plan was not "trade or commerce," $95 \mathrm{~F}$. Supp. at 118, found no merit to plaintiff's allegations and dismissed the case. Id. at 120. The Supreme Court affirmed on the merits and avoided the learned profession issue.

For a discussion of the "learned professions" exemption, see Bauer, Professional Activities and the Antitrust Laws, 50 N.D. LAw. 570 (1975).

3. 421 U.S. 773 (1975).

4. Much of this activity has been initiated by the federal enforcement agencies. The Federal Trade Commission's (FTC) successful attack on the relative value scales of orthopedic surgeons and obstetrician-gynecologists has attracted considerable attention. See FTC News Summary, July 16,1976 , at 1 . The Commission has proceeded in a similar fashion with reference to other specialties, e.g., anesthesiologists. The FTC has also successfully halted an alleged boycott by a medical association of a health maintenance organization (HMO) and its physicians. FTC News Summary, Sept. 1, 1976, at 1. The rebate of charges by laboratories to physicians has been precluded by a consent decree. FTC News Summary, July 8, 1977, at 1. The Commission has also issued a trade regulation that would allow ophthalmologists and optometrists to advertise the prices of their services. See 865 Antitrust \& TRADE REg. ReP. (BNA) A-20, F-1 (1978); 873 ANTtTRUst \& Trade Reg. Rep. (BNA) A-8 (1978). Perhaps most noteworthy is the FTC's attack on the AMA's proscription of physician advertising. See Wall St. J., Dec. 23, 1975, at 1, col. 3.

Several investigations are also underway. The Commission has announced an investigation of physician control of Blue Shield medical services plans. 753 ANTITRUST \& TRADE REg. REP. (BNA) A-9 (1976). The FTC has also recently indicated its concern for the anticompetitive consequences of current medical school accreditation practices. See 815 ANTITRUST \& TRADE Rea. REP. (BNA) A-2 (1977).

There are numerous other investigations and legal actions in the health area more broadly 
In a mixed economy such as that of the United States, primary reliance is normally placed on a decentralized form of economic decision making in which the basic economic units are perceived as firms (which produce and supply goods and services) and households (which provide labor and consume goods and services). ${ }^{5}$ Over time, government has become another important actor in the economic system, primarily as a purchaser of goods and services and, in the medical sector, as the financier of private purchaser decisions for beneficiaries of such programs as Medicare (for the elderly) and Medicaid (for the categorically poor). To a more limited degree, government has also become an actual supplier of medical services to defined populations through such programs as the Veterans Administration, Indian health programs and sundry state and local hospitals and clinics. ${ }^{6}$

The fundamental question that government must confront in structuring economic institutions is its own appropriate role. ${ }^{7}$ The nature and scope of governmental intervention in the economic sector is a basic issue whose determination will turn on normative premises about equity and on perceptions about the most effective means of achieving allocative efficiency. Economic efficiency and social equity have special relevance to health where accelerating costs have compelled consideration of efficiency issues, and where expectations have been generated about an undefined right to health care. ${ }^{8}$

Traditionally, governmental intervention flows from identification of a market defect. Conventional public finance criteria specify four grounds for governmental intervention to improve allocative efficiency: externalities, public goods, natural monopoly and other market imper-

defined. Illustrative is the Commission's investigation of whether state antisubstitution laws constitute an unfair method of competition, see FTC News Summary, Aug. 6, 1976, at 3, and its proposed rule concerning advertising for over-the-counter drugs. See FTC News Summary, Oct. 5 , 1976. Cf. Virginia State Bd. of Pharmacy v. Virginia Citizens Consumer Council, Inc., 425 U.S. 748 (1976) (overturning state ban on advertising of drugs).

5. See generally Fuchs, Health Care and the United States Economic System-An Essay in Abnormal Physiology, in Economic ASPECTS OF HeALTH CARE 95 (J. McKinlay ed. 1973).

6. For discussions of the Veterans Administration medical delivery system, see Lipsky, McCrary, Prottas \& Sapolsky, The Future of the Veterans' Health Care System, $1 \mathrm{~J}$. HeAlth Pol., PoL'Y \& L. 285 (1976); Sapolsky, America's Socialized Medicine: The Allocation of Resources within the Veterans' Health Care System, 25 Public PoliCY 359 (1977).

7. See Blumstein \& Zubkoff, Public Choice in Health:Problems, Politics, and Perspectives on Formulating National Health Policy, INT'L J. HEALTH SERVICES (forthcoming, 1978); Blumstein \& Zubkoff, Perspectives on Government Policy in the Health Sector, 51 Milbank Memorial Fund Q.: HeALTH \& Soc'Y 395 (1973).

8. Fein, On Achieving Access and Equity in Health Care, in Economic AsPECTS OF HEALTH CARE 23 (J. McKinlay ed. 1973). See generally Blumstein \& Sloan, Health Planning and Regulation Through Certificate of Need: An Overview, 1978 UTAH L. Rev. 3. 
fections. ${ }^{9}$ It is widely conceded that with respect to natural monopolies, competition is not an effective means of promoting economic efficiency. In these industries there are tremendous economies of scale, but they can be realized only at a very high level of output. If, however, the market is divided among several competitors, none will be able to take advantage of the economies. Therefore, in these industries, a monopolistic market structure provides the greatest potential for economic efficiency. Given the monopolistic result, most analysts conclude that some form of regulation, primarily of prices, is necessary and desirable as a means of constraining the discretion of the monopolist. Since prices in a regulated industry have been determined under a system of rate of return on capital investment, it has become necessary also to impose restrictions on investment in the industry so as to control the allocation of resources to the industry.

Public goods, which exist when nonpaying beneficiaries cannot be excluded from benefiting from a service, even if they do not pay a specified price, pose a similar situation. In order to exact a fair contribution from beneficiaries of such a governmental good or service some form of governmental coercion may be necessary. In this situation, coercion generally takes the form of taxation, with the government actually providing the public good on its own, essentially as a producer.

With respect to the problems of externalities and other market imperfections, the justifications for governmental intervention are different. There are several alternative means for addressing these problems. On the one hand, policy can be aimed at perfecting the market by remedying the specific imperfections or by devising means for internalizing the external effects. On the other hand, a policy maker could conclude that perfecting the market is either impossible or not worth the trouble and could substitute for the market a regulatory system of decision making, which relies on bureaucratic techniques of command and control. ${ }^{10}$ In the medical sector, the regulatory approach has generally been preferred. The political appeal of regulation has been described as follows:

Regulation seems to be the approach that addresses itself most directly to the perceived problem. If prices are "too high," set rates; if desired services are not available in some area or for some people, fix the responsibility on some institutional organization to see that they are made available; if the quality of service is too low, set standards. ${ }^{11}$

9. See Blumstein \& Zubkoff, Perspectives, supra note 7, at 401-07.

10. See generally C. Schultze, The Public Use of Private Interest (1977).

11. Ball, Background of Regulation in Health Care, in Controls on Health CARE 3, 7 (Nat'l Academy of Sciences, Inst. of Medicine 1974). See also Iglehart, The Cost and Regulation 
It is also true that both market and regulatory procedures can be used to achieve equity goals in economic policy. Charles L. Schultze, Chairman of President Carter's Council of Economic Advisors, has revived interest in the use of market mechanisms among those who prefer active government intervention to promote social policy objectives. Recognizing that market forces and incentives can be used as a way of "supplementing the market and correcting its failures rather than supplanting it,"12 Schultze suggests careful consideration of strategies that emphasize procedurally oriented, decentralized processes of decision making in order to effectuate social policy goals:

Once the decision to intervene has been taken, there remains a critical choice to be made: should intervention be carried out by grafting a specific command-and-control module-a regulatory apparatus-onto the system of incentive-oriented private enterprise, or by modifying the informational flow, institutional structure, or incentive pattern of that private system? Neither approach is appropriate to every situation. But our political system almost always chooses the command-and-control response and seldom tries the other alternatives, regardless of whether that mode of response fits the problem. ${ }^{13}$

In the health industry, the "inexorable trend has been for expanded bureaucratic regulatory controls to implement politically determined health objectives." 14 The call for reconsideration of market mechanisms for the achievement of efficiency and equity goals has included drawing attention to such tools as advertising, ${ }^{15}$ alternative delivery systems such as Health Maintenance Organizations (HMOs), ${ }^{16}$ financial disincentives (deductibles and coinsurance), ${ }^{17}$ constructive use of competition among private insurers, ${ }^{18}$ creative use of the legal doc-

of Medical Technology: Future Policy Directions, 55 Milbank Memorial Fund Q:: Health \& Soc'y 25, 35-38 (1977).

12. See Havighurst, Speculations on the Market's Future in Health Care, in REGULATING Health Facilities Construction 249, 268 (C. Havighurst ed. 1974).

13. C. SChulTZE, supra note 10, at 13.

14. Blumstein \& Zubkoff, Public Choice in Health, supra note 7.

15. See note 4 supra.

16. See Havighurst, Blumstein \& Bovbjerg, Strategies in Underwriting the Costs of Catastrophic Disease, 40 LAw \& CONTEMP. РROB. 122, 153-55, 193-95 (1976); Havighurst, Health Maintenance Organizations and the Market for Health Services, 35 LAW \& CONTEMP. PROB. 716 (1970).

17. See, e.g., Enthoven, Consumer-Choice Health Plan: Inflation and Inequity in Health Care Today: Alternatives for Cost Control and an Analysis of Proposals for National Health Insurance, 298 NEw ENG. J. MED. 650 (1978); Enthoven, Consumer-Choice Health Plan: A National Health Insurance Proposal Based on Regulated Competition in the Private Sector, 298 NEw ENG. J. MED. 709 (1978); Havighurst, Blumstein \& Bovbjerg, supra note 16, at 178-81, 188-93.

18. See Havighurst, Controlling Health Care Costs: Strengthening the Private Sector's Hand, 1 J. HEALTH POL., POL'Y \& L. 471 (1977). 
trine of informed consent ${ }^{19}$ and use of paraprofessionals as a means of better informing consumers. ${ }^{20}$

It is only natural and proper that consideration also be given to the creative use of the antitrust laws as a market-oriented strategy toward social control of the health sector. Given the existing degree of regulation of the medical services delivery system, antitrust issues must be considered in determining how competing systems of social control can be accommodated. The initial focus of this Article, therefore, is the interrelationship between antitrust doctrine and potentially conflicting state regulatory programs. The fundamental issue that will be considered in the first section is how a system of federal antitrust law can be accommodated with state regulation that often is premised upon inconsistent policies toward both equity and efficiency. This Article will then deal with the particular antitrust issues raised by the presence of state action in the medical care field. Specifically, we will show that this state involvement can serve as a sword as well as a shield with respect to antitrust enforcement.

As a shield, state action may exempt certain anticompetitive conduct from coverage under the antitrust laws because of the so-called Parker v. Brown doctrine. In the 1943 case of Parker v. Brown, ${ }^{21}$ the Supreme Court held that the Sherman Act was meant to apply to "individual and not state action."22 While recent Supreme Court cases have reaffirmed the existence of some exemption, ${ }^{23}$ they have done as much to confuse as to explain the contours of the state action exemption. This Article will suggest that the state action cases can be explained as manifestations of two distinct federalism concerns, each stemming from different constitutional sources: one reflecting the states' eleventh amendment sovereign immunity and the other reflecting a recognition of the states' tenth amendment reserved powers. This double exemp-

19. See, e.g., Blumstein \& Zubkoff, Perspectives, supra note 7, at 419; Note, Restructuring Informed Consent: Legal Therapy for the Doctor-Patient Relationship, 79 YALE L.J. 1533 (1970).

20. See Blumstein \& Zubkoff, Perspectives, supra note 7, at 419-20.

21. 317 U.S. 341 (1943). For recent discussions of the Parker v. Brown doctrine, see Donnem, Federal Antitrust Laws Versus Anticompetitive State Regulation, 39 ANTITRUST L.J. 950 (1970); Handler, The Current Attack on the Parker v. Brown State Action Doctrine, 76 Colum. L. REv. 1 (1976); Posner, The Proper Relationship Between State Regulation and the Federal Antitrust Laws, 49 N.Y.U.L. Rev. 693 (1974); Slater, Antitrust and Government Action: A Formula for Narrowing Parker v. Brown, 69 Nw. U.L. Rev. 71 (1974); Verkuil, State Action, Due Process and Antitrust: Reflections on Parker v. Brown, 75 CoLum. L. Rev. 328 (1975); Comment, The State Action Exemption in Antitrust: From Parker v. Brown to Cantor v. Detroit Edison Co., 1977 Duke L.J. 871.

22. 317 U.S. at 352 .

23. See, e.g., Bates v. State Bar of Ariz., 433 U.S. 350 (1977). 
tion would shield some state regulation in the health care field from coverage under the antitrust laws.

Perhaps suprisingly, however, far from immunizing certain activity from antitrust scrutiny, the presence of state action in some contexts can exacerbate the antitrust susceptibility of certain anticompetitive conduct. Thus, where a state agency undertakes to restrict access to certain facilities or equipment, that governmentally created scarcity can have the effect of increasing the market power of those who are the beneficiaries of the government's preferred treatment. If the private party then seeks to take advantage of govermentally conferred market power-for example, through a tying arrangement-the existence of state action could provide the necessary sword ("market power") for imposing antitrust liability that otherwise might not exist. The final part of the Article, therefore, will show that, while in some circumstances the presence of state action can protect against antitrust liability, in other situations it is the very existence of that governmental action that could have the effect of triggering an antitrust violation.

\section{The Problems Posed by Accommodating Federal ANtitrust and State Regulatory Policies}

The Parker v. Brown doctrine dictates that some accommodation must be sought between federal interests in antitrust enforcement and principles of federalism and comity, ${ }^{24}$ which command federal deference to state police power authority. ${ }^{25}$ Defining the contours of Parker v. Brown immunity-for states and for private parties-is therefore an attempt at resolving two different, though related, tensions.

The first tension is between different techniques for structuring economic activity. Reliance on the market and decentralized decision making for achieving equity and efficiency objectives is one ap-

24. In Younger v. Harris, 401 U.S. 37 (1971), the Supreme Court in an opinion by Justice Black held that a federal court could not enjoin an ongoing good-faith state criminal proceeding. Under the doctrine of comity there announced, federal courts must defer to state courts even where federal constitutional issues are raised, provided there is no bad-faith harassment and provided that federal claims can be adequately heard in appropriate state proceedings. The Younger case has spawned numerous progeny. See, e.g., Trainor v. Hernandez, 431 U.S. 434 (1977); Juidice v. Vail, 430 U.S. 327 (1977); Hicks v. Miranda, 422 U.S. 332 (1975); Huffman v. Pursue, Ltd., 420 U.S. 592 (1975); Samuels v. Mackell, 401 U.S. 66 (1971). But cf. Wooley v. Maynard, 430 U.S. 705, 709-12 (1977) (permitting federal injunctive relief after three prosecutions under a challenged state law); Doran v. Salem Inn, Inc., 422 U.S. 922 (1975) (permitting preliminary injunctive relief where a plaintiff is properly in federal court seeking declaratory relief); Steffel v. Thompson, 415 U.S. 452 (1974) (permitting federal declaratory relief against threatened-as opposed to pending-state prosecution, even without a showing of bad-faith harassment).

25. See generally, Fiss, Dombrowski, 86 YALE L.J. 1103 (1977); Friendly, Federalism: $A$ Foreword, 86 YALE L.J. 1019 (1977). 
proach. ${ }^{26}$ Another approach is to supplant the market with a centralized political command-and-control regulatory apparatus for pursuing social goals. ${ }^{27}$ Antitrust policy assumes that the market can function adequately if the preconditions of competition can be maintained. Accordingly, in this view, governmental intervention should focus on deviations from or imperfections in the market system, with an eye toward restoring an environment that permits the market's proper functioning, ${ }^{28}$ antitrust law is seen in essence as a procedural policy tool.

Regulation, by contrast, is born of a skepticism of market perfection as a realistic, achievable goal. Its proponents view the system of essentially uncontrolled, private, decentralized decision making as unacceptably unpredictable. ${ }^{29}$ Regulation can be adopted as a vehicle for promotion of allocative efficiency, but is often most highly touted as a mechanism for implementing substantive policy goals, ${ }^{30}$ typically either by coercive intervention ${ }^{31}$ or by a form of internal subsidization. ${ }^{32}$ Indeed, only recently have those who seek to further redistributive or other equitable policy goals recognized the possibilities of market incentives in effectuating social policy. ${ }^{33}$

Reconciling federal antitrust policy with state regulatory initiatives thus requires a sensitive melding of fundamentally different orientations toward structuring economic activity. Nevertheless, the cases indicate that such a blending is necessary at the interstices between regulatory and competitive approaches to social ordering, ${ }^{34}$ and Parker v. Brown dictates that the same accommodation be made even when the different systems reflect policy determinations by different levels of government.

The second tension raised by a Parker $v$. Brown analysis is that between federal and state or local policies. Under the supremacy

26. See, e.g., Blumstein \& Zubkoff, Perspectives, supra note 7, at 412-21.

27. See generally C. SCHULTZE, supra note 10.

28. See Blumstein \& Zubkoff, Public Choice in Health, supra note 7.

29. Id.

30. See Blumstein \& Sloan, supra note 8.

31. See, e.g., Navarro, Justice, Social Policy, and the Public's Health, 15 Med. Care 363 (1977); Navarro, National Health Insurance and the Strategy for Change, 51 Milbank MEM. Fund Q.: Health \& Soc'y 223 (1973).

32. See Posner, Taxation by Regulation, 2 Bell J. Econ. \& Mat. SCI. 22 (1971). Internal subsidization occurs when regulation permits a firm to price some services well above cost on the condition that certain other services, thought to be needed by the public, are priced at less than cost. One example is the requirement that freight shippers serve outlying areas at below-cost rates, subsidized by revenues derived from intercity runs. For an analysis of internal subsidies in hospital regulation, see Havighurst, Regulation of Health Facilities and Services by "Certificate of Need," 59 VA. L. Rev. 1143, 1188 (1973).

33. See C. Schutrize, supra note 10.

34. See, e.g., Cantor v. Detroit Edison Co., 428 U.S. 579 (1976). 
clause of the Constitution, ${ }^{35}$ federal policy prevails where it comes into conflict with incompatible or inconsistent state policy. ${ }^{36}$ Nonetheless, there is a strong tradition of federalism which counsels caution before federal policy is construed to supersede state policies that can peacefully coexist with federal law. ${ }^{37}$ The Parker v. Brown doctrine reflects an acute judicial sensitivity to these federalism values, which ultimately are derived from constitutional structure and reinforced not only by tradition but by a substantial body of decisional law. ${ }^{38}$ In a variety of contexts, the Court has relied on this notion of deference or comity to conclude that federal policies ought not be pushed to their constitutional limits, absent explicit congressional expression of a desire to extend federal power to that extent. ${ }^{39}$ In several very recent decisions, the Court has recognized a constitutional dimension to this federalism value which limits the permissible degree of direct or indirect federal intrusion on state decision making processes and allocation of state financial resources. ${ }^{40}$

The problem posed by Parker v. Brown is to determine the scope of autonomy that states as states should have within an overarching federal antitrust framework. ${ }^{41}$ In order to develop an analytical framework that will facilitate thinking about the accommodation between federal antitrust policy and state anticompetitive activity, it is helpful first to consider the general problems of the role of antitrust in a regulatory setting and second to consider the overall issues raised by concerns of federalism.

\section{A. Antitrust vs. Regulation.}

In recent years the tension between antitrust principles and much regulation has become readily apparent. ${ }^{42}$ Review of the judicial treat-

35. U.S. Const. art. VI, cl. 2.

36. See, e.g., Jones v. Rath Packing Co., 430 U.S. 519 (1977). See generally L. TRIBE § 6-23.

37. See, e.g., Florida Lime \& Avocado Growers, Inc. v. Paul, 373 U.S. 132 (1963).

38. See Posner, supra note 21, at 703-05; Note, Parker v. Brown: A Preemption Analysis, 84 YALE L.J. 1164 (1975). See generally L. TRIBE \$\& 6-23 to 6-27.

39. See, e.g., Employees v. Department of Public Health \& Welfare, 411 U.S. 279, 285 (1973) (Court will not infer congressional intent to deprive states of eleventh amendment immunity unless Congress indicates its intent "in some way by clear language"); United States v. Bass, 404 U.S. 336, 349 (1971) (Court will narrowly construe a federal criminal statute since "unless Congress conveys its purposes clearly, it will not be deemed to have significantly changed the federal-state balance"); Rice v. Santa Fe Elevator Corp., 331 U.S. 218, 230 (1947) (in a preemption case, the Court will assume "that the historic police powers of the States were not to be superseded by the Federal Act unless that was the clear and manifest purpose of Congress").

40. National League of Cities v. Usery, 426 U.S. 833 (1976); Hughes v. Alexandria Scrap Corp., 426 U.S. 794 (1976).

41. See, e.g., Posner, supra note 21, at 707-27; Slater, supra note 21, at 73-78, $104-08$.

42. See generally Donnem, supra note 21 . 
ment of the interface between regulation and antitrust shows different patterns. Essentially, there are two categories of industries to which the antitrust laws either do not apply or else apply in some limited fashion. First, there are industries which benefit from a specific statutory exemption from all or part of the antitrust laws. ${ }^{43}$ Despite such an express exemption, on several occasions the Supreme Court has indicated that it will closely scrutinize claims of antitrust immunity. As the Court observed in FMC v. Seatrain Lines, Inc., 44 "exemptions from antitrust coverage are strictly construed." 45

Of greater importance to our discussion is the extent to which industries for which no specific exemption applies, but which nevertheless are heavily regulated by other legislation, enjoy immunity from the antitrust laws. ${ }^{46}$ Most of the issues arising in this context have addressed the question of whether the antitrust courts or the regulatory agencies have "primary jurisdiction." 47 Unfortunately, the term "primary jurisdiction" has not enjoyed precise definition. Two quite different usages have arisen in the case law. The first, which is used to characterize those settings where judicial jurisdiction has been replaced by administrative regulation, ${ }^{48}$ is a true exemption. One recent illustrative case is Hughes Tool Co. v. Trans World Airlines, Inc. ${ }^{49}$ in which

43. See L. Sullivan, HandbooK of the LaW of ANtitrust 717, $743-44$ (1977).

44. 411 U.S. 726 (1973).

45. Id. at 733. A leading case and suitable illustration of this judicial attitude is United States v. Borden Co., 308 U.S. 188 (1939). In that case the defendants sought to dismiss an indictment that charged a dairy cooperative with conspiracy in conjunction with its distributors and others to fix milk prices. Although the Capper-Volstead Act, 7 U.S.C. $\$ \$ 291-292$ (1976), immunized cooperatives from jointly processing and marketing their products, the Court upheld the indictment, reasoning that the statutory immunity was not absolute and that immunity was lost when the cooperative conspired with persons outside its membership to restrain trade. Other cases involving the insurance and labor exemptions seem to underscore the Court's concern that the challenged practice fall clearly within the ambit of exempted conduct. For example, the McCarran-Ferguson Act, 15 U.S.C. $\$ \S 1011-1015$ (1976), exempts the business of insurance from antitrust only if and to "the extent that such business is . . regulated by State law." 15 U.S.C. \& 1012(b) (1976). In a series of cases the Supreme Court has stated that simple state regulation of the insurance companies will not suffice to confer immunity unless the focus of that regulation is on the company's relationship with its policyholders, see, e.g., SEC v. National Securities, Inc., 393 U.S. 453 (1969), and that a multistate company cannot enjoy the exemption unless each of the states in which it does business undertakes that type of regulation. See FTC v. Travelers Health Ass'n, 362 U.S. 293 (1960).

46. In United States v. Philadelphia Nat'l Bank, 374 U.S. 321 (1963), Justice Brennan observed that the "fact that banking is a highly regulated industry critical to the Nation's welfare makes the play of competition not less important but more so." Id. at 372 .

47. $C f$. Verkuil, supra note 21 , at 340-57 (suggesting use of primary jurisdiction approach in Parker v. Brown context).

48. See, e.g., United States v. National Broadcasting Co., 1974-1 TRADE CASEs $\llbracket 74,885$, at 95,989 (C.D. Cal. 1973). See also ABA, Antitrust LAW Development 412 (1975).

49. 409 U.S. 363 (1973). In that case an airline brought suit against its former parent corporation alleging that transactions between the two during the period of the parent-subsidiary rela- 
the Supreme Court held that " $\mathrm{CAB}$ jurisdiction . . . preempts the antitrust field." 50 However, regulation may give rise to primary, but not necessarily exclusive, jurisdiction, where courts defer to prior agency adjudication, all the while reserving to themselves the ultimate disposition of the antitrust matter. ${ }^{51}$ Unfortunately, it is difficult to generalize in this area. As Professor Lawrence Sullivan has observed, "there are, in a sense, as many sets of exemption doctrines as there are industries subject to state or federal regulation." 52 However, despite the Court's

tionship violated the antitrust laws. The defendant argued that the transactions which were the basis of the plaintiffs suit had been approved by the Civil Aeronautics Board and that Board approval insulated the alleged illegal conduct from antitrust scrutiny.

50. Id. at 385.

51. See, e.g., Ricci v. Chicago Mercantile Exch., 409 U.S. 289 (1973); United States v. ICC, 396 U.S. 491 (1970); McLean Trucking Co. v. United States, 321 U.S. 67 (1944). While the regulatory agencies must consider competitive impact, such factors are not necessarily determinative. In this context, there is some authority holding that regulatory commissions must consider antitrust principles in their own decision making. Indeed, there is authority in Federal Maritime Comm'n v. Aktiebolaget Svenska Amerika Linien, 390 U.S. 238 (1968), that serious anticompetitive effects "alone will normally constitute substantial evidence that the [practice] is 'contrary to the public interest,' unless other evidence in the record fairly detracts from the weight of this factor." Id. at 246.

Other cases go even further, indicating that deference by antitrust courts to regulatory agencies is not only unnecessary but ill-advised. Thus, in California v. FPC, 369 U.S. 482 (1962), EI Paso Natural Gas Company had applied to the FPC for approval of a merger with another gas pipeline company, as required by the Natural Gas Act. The government challenged the merger and sought unsuccessfully to persuade the FPC to stay its hearing until the antitrust matter was decided. The antitrust court then elected to stay its case until the FPC had completed its investigation. That stay was successfully appealed by the government, and the Supreme Court held that FPC approval would not render the merger immune under the antitrust laws. Moreover, the Court cautioned that prior FPC approval might wrongly influence the ultimate decision of the antitrust court.

52. L. Sullivan, supra note 43 , at 743 . The case law seems plagued by inconsistencies-at least at first blush. For example, the Supreme Court's decision in Ricci v. Chicago Mercantile Exch., 409 U.S. 289 (1973), decided the same year as Hughes Tool, is arguably inconsistent with the latter decision. In Ricci a disgruntled broker brought an action against the exchange, alleging injury by the wrongful transfer of its membership to another broker. While the Supreme Court upheld an order staying antitrust action until the dispute was adjudicated before the Commodity Futures Trading Commission, the Court also stated that the antitrust laws were compatible with the regulatory statute. The antitrust action was evidently stayed as a matter of administrative convenience in the hope that the commission's proceedings would assist the federal court in deciding whether the antitrust and regulatory principles were compatible.

A third case decided that same year was Otter Tail Power Co. v. United States, 410 U.S. 366 (1973). There the defendant utility contended that the government's antitrust allegation-Otter Tail's refusal to "wheel" power of its competitors on its transmission line-was inappropriately before the Court. The FPC, the utility argued, had the sole authority to order it to transport the power of others. The Supreme Court found no antitrust exemption as it had in Hughes Tool, nor did it enjoin further antitrust proceedings pending agency review as in Ricci. These three decisions, all rendered the same year, illustrate the difficulty of making primary jurisdiction generalizations.

Mention must also be made of the recent decision, United States v. National Ass'n of Sec. Dealers, Inc., 422 U.S. 694 (1975), where the Court found an implied repeal of the antitrust laws 
reliance on the peculiar statutory characteristics of particular federal regulatory programs, the general approach remains one of strictly scrutinizing claims for exemption.

\section{B. Federal/State Accommodation.}

While the scope of antitrust enforcement in the context of federal regulation requires a sensitive balancing of the competing policies of federal programs, the problem is somewhat different with regard to the application of federal antitrust laws to state regulatory activities. Because of the hierarchical relationship between federal and state governments imposed by the supremacy clause, ${ }^{53}$ accommodation of federal and state policies normally focuses on the purpose of the federal legislation and its intended scope. ${ }^{54}$ Under traditional preemption doctrine, the Court typically will determine whether state laws conflict directly with federal law; whether federal laws are designed to occupy the field, and thereby preempt state laws even in the absence of incompatibility or a direct conflict; or whether the state laws frustrate the purpose of the federal program, thereby falling under the supremacy clause because of their inconsistency with the overall design of federal policy. ${ }^{55}$ Presumably, under a preemption analysis, federal antitrust laws could be construed to supersede all inconsistent or incompatible state regulatory activity, although through the Parker v. Brown doctrine the Court has declined to extend application of the antitrust laws that far. ${ }^{56}$ At some point, however, principles of federalism-derived from the tenth $^{57}$ and eleventh amendments ${ }^{58}$-would likely impose an independent, constitutional limitation on the preemptive power of the federal government in this area.

necessary to the regulatory scheme. In that case the government challenged the industry practice of broker-dealers combining to establish the resale prices of mutual fund shares in secondary market transactions between dealers and others. Although the relevant securities statutes did not expressly authorize or require the defendants' conduct, the Court rejected the government's contention that the SEC's exercise of regulatory authority was insufficient to give rise to an implied immunity. Moreover, the Court held that the SEC's authority would be seriously compromised if the allegations were deemed actionable: "In this instance the antitrust laws must give way if the regulatory scheme established by the Investment Company Act is to work." Id. at 729-30.

53. U.S. CoNST. art. VI, cl. 2.

54. See text accompanying notes 35-39 supra. See also Cantor v. Detroit Edison Co., 428 U.S. 579, 605 (1976) (Blackmun, J., concurring) ('ihe Sherman Act's pre-emptive effect . . . is . . . one of congressional intent"); id. at 624-25 n.10 (Stewart, J., dissenting).

55. Jones v. Rath Packing Co., 430 U.S. 519, 525-26 (1977).

56. Cantor, 428 U.S. at 605 (Blackmun, J., concurring) ("[n]o one denies that Congress could, if it wishes, override those state laws whose operation would subvert the federal policy of free competition in interstate commerce").

57. U.S. CoNsT. amend. $X$, quoted at note 184 infra.

58. U.S. CoNST. amend. XI, quoted at note 144 infra. 
The general problem of determining how to accommodate federal policies, enacted under the broad authority of the commerce clause, with potentially inconsistent or incompatible state policies is not unfamiliar. In some situations, Congress has explicitly carved out particular exemptions from the application of federal programs or policies in deference to state regulatory discretion and autonomy. This has been true, for example, in the insurance regulation field, ${ }^{59}$ until recently in the area of fair trade laws ${ }^{60}$ and in the so-called right-to-work provisions of federal labor legislation. ${ }^{61}$ Where Congress has not been explicit, however, the Court has had to determine which state programs and policies could be permitted to coexist with the federal statutes and regulations.

In order to resolve potential federal/state authority disputes, the Court must search for federal intent and will often examine in detail evidence of intent from the legislative history of a statutory enactment. ${ }^{62}$ In the case of the antitrust laws, as with the interpretations of other long-standing federal legislation, ${ }^{63}$ the difficulty of divining intent is apparent. This is especially true with respect to the Sherman Act, which was enacted pursuant to the commerce clause in an era when views of federal authority under the commerce power were strikingly different from those currently held.

Specifically, the scope of federal authority was much more circumscribed in 1890, at the time the Sherman Act was enacted, because of restrictive judicial interpretations of what constituted interstate commerce and how far the federal government could go in regulating activity that might not itself be in commerce, but that clearly had a significant effect on commerce. ${ }^{64}$ Moreover, in 1890 the Court still had not finally buried the notion of dual federalism, which held that federal and state authority were separate, distinct and not overlapping. ${ }^{65}$ That

59. See McCarran-Ferguson Act, 15 U.S.C. \$§ 1011-1015 (1976).

60. Consumer Goods Pricing Act of 1975, Pub. L. No. 94-145, 89 Stat. 801 (codified at 15 U.S.C. $\S \S 1,45(a)(1976))$.

61. 29 U.S.C. $\$ 164(b)(1970)$.

62. See, e.g., Campbell v. Hussey, 368 U.S. 297, 301 (1961); Huron Portland Cement Co. v. City of Detroit, 362 U.S. 440, 444-48 (1960).

63. See, e.g., Douglas v. Seacoast Prod., Inc., 431 U.S. 265 (1977).

64. See Cantor, 428 U.S. at $605-06$ (Blackmun, J., concurring). See also id. at 635 (Stewart, J., dissenting); Hospital Bldg. Co. v. Rex Hosp. Trustees, 425 U.S. 738, 743 n.2 (1976).

65. See, e.g., Hammer v. Dagenhart, 247 U.S. 251, 272 (1918) ("the production of articles, intended for interstate commerce, is a matter of local regulation ... . If it were otherwise, all manufacture intended for interstate shipment would be brought under federal control to the practical exclusion of the authority of the states") (emphasis added); United States v. E.C. Knight Co., 156 U.S. 1, 14-15 (1895) (broad construction of federal authority under the commerce clause would give Congress vast power "to the exclusion of the States . . . . The power being vested in Congress and denied to the States, it would follow as an inevitable result that the duty would 
is, under this view of federal/state relations, states were unable to legislate on matters of interstate commerce. Thus, if federal power were found to exist under the commerce clause, that finding would thereby deprive the states of authority to regulate on the matter. Consequently, the need to accommodate federal and state policies did not exist; if the federal government had legislative authority, then the states did not. The modern view of concurrent federal and state authority necessitates the kind of sensitive intergovernmental accommodation which would have been unforeseeable for an 1890 Congress. ${ }^{66}$

Because of the evolution of commerce clause doctrine, the legislative history cannot be determinative of a preemption analysis. Rather, other sources must be examined to ascertain intent-to guide a court's attempted accommodation. In this regard, constitutionally based principles become important in serving as a helpful framework for interpretation of an ambiguous federal mandate. The Court has relied on general commerce clause principles of national uniformity in interpreting the preemptive scope of federal law; ${ }^{67}$ in the context of federal antitrust law and inconsistent state action, the Court would naturally look to general principles of federalism and comity in order to guide its inquiry into the intended scope of federal antitrust law. ${ }^{68}$

The preemption analysis, even guided by constitutionally based principles of federalism, is not finally determinative, however, of federal/state power relationships; rather, the preemption doctrine serves as a convenient vehicle for developing a dynamic political conversation

devolve on Congress to regulate all these delicate, multiform and vital interests-interests which in their nature are and must be local in all the details of their successful management") (quoting Kidd v. Pearson, 128 U.S. 1, 21 (1888)).

66. See Cantor, 428 U.S. at 635-36 (Stewart, J., dissenting):

It was this retroactive expansion of the jurisdictional reach of the Sherman Act that was in large part responsible for the advent of the Parker doctrine. . . . Under the original understanding of the draftsmen of the Sherman Act, such in-state production, like instate manufacturing, would not have been subject to the regulatory power of Congress under the Commerce Clause and thus not within the "jurisdictional" reach of the Sherman Act. ... If the state of the law had remained static, the Parker problem would rarely, if ever, have arisen.

See also Blumstein, Some Intersections of the Negative Commerce Clause and the New Federalism: The Case of Discriminatory State Income Tax Treatment of Out-of-State Tax-exempt Bonds, 31 VAND. L. REv. 473 (1978).

67. See, e.g., Douglas v. Seacoast Prod., Inc., 431 U.S. 265 (1977) (relying in the last part of the opinion on policies found in the commerce clause); City of Burbank v. Lockheed Air Terminal, Inc., 411 U.S. 624 (1973) (relying in part on the need for uniformity, a consideration often part of commerce clause analysis).

68. See Rice v. Santa Fe Elevator Corp., 331 U.S. 218, 230 (1947) (the purpose of Congress "may be evidenced in several ways . . . [T] he Act of Congress may touch a field in which the federal interest is so dominant that the federal system will be assumed to preclude enforcement of state laws on the same subject"). See generally Note, Pre-emption as a Preferential Ground: A New Canon of Construction, 12 STAN. L. REv. 208 (1959). 
between the Court and Congress. ${ }^{69}$ If the Court concludes that federal law does not necessarily mandate supersession of state law in any given situation, Congress still has the option of overturning the state policy by enacting more explicit legislation that would make federal preemptive intent clear. In this circumstance, the states would be compelled to acquiesce unless there were an independent constitutional source of limitation that would bar the federal action under challenge. ${ }^{70}$

Thus, by finding state action exempt from federal law on preemption grounds, a court defers the resolution of an ultimate constitutional question. It enters into a political dialogue with Congress, inviting it to respond to judicial narrowing of federal law by expanding it to cover very specific situations. Thus, if there is a constitutional question of federal power that needs to be addressed, it is up to Congress to shape the constitutional issue for the court-and, in essence, to invite the court to adjudicate the ultimate constitutional question. ${ }^{71}$

The Court's attempted accommodation between the federal antitrust laws and inconsistent anticompetitive state activity has typically been viewed in preemption terms. We will examine the cases in this light, but will add an interpretive gloss that derives from principles of eleventh and tenth amendment federalism. Before turning to the development of an analytical framework, however, we will briefly set forth the relevant Supreme Court cases in the area.

\section{From PARKER to BATES: What Is State Action?}

Parker v. Brown, the decision that originated the state action exemption, did little to define its scope. The case involved a raisin producer's attempt to enjoin enforcement of the California Raisin Proration Program. The program was designed to stabilize raisin prices by authorizing state officials to appropriate a portion of each producer's output. The Parker decision reversed a three-judge district court's is-

69. See Note, supra note 68 .

70. Cf. L. TRIBE § 3-37. Professor Tribe argues that Congress, by unequivocally clear legislation, can abrogate states' eleventh amendment immunity but that a "sufficiently 'drastic invasion of state sovereignty' could be invalidated notwithstanding even the clearest possible expression of congressional purpose, but any such invalidation would rest ultimately on tenth rather than eleventh amendment grounds." Id. 142 (quoting Fry v. United States, 421 U.S. 542, $547-48$ n.7 (1975)) (footnotes omitted).

71. This in essence is what the Court has done in the area of standing, in which it has distinguished between Article III standing - the constitutional minimum of injury in fact-and prudential standing -a nonconstitutional, self-imposed restriction on access to the Court. With respect to prudential standing restrictions, the Court has invited Congress to legislate broader standing if it wishes the Court to review constitutional claims of designated litigants in specified areas. See Warth v. Seldin, 422 U.S. 490 (1975); United States v. Richardson, 418 U.S. 166, 180 (1974) (Powell, J., concurring). See also A. Bickel, The Least Dangerous Branch (1962). 
suance of an injunction. ${ }^{2}$

Writing for a unanimous Court, Chief Justice Stone found that the state price stabilization program did not violate the federal antitrust laws. ${ }^{73} \mathrm{He}$ assumed that "the California prorate program would violate the Sherman Act if it were organized and made effective solely by virtue of a contract, combination or conspiracy of private persons, individual or corporate"74 and indeed observed that the program eliminated price competition among producers. ${ }^{75}$ However, noting that the state program "derived its authority and its efficacy from the legislative command of the state," ing in the language of the Sherman Act or in its history . . . suggests that its purpose was to restrain a state or its officers or agents from activities directed by its legislature."77 The policy underlying this conclusion was put simply: "In a dual system of government in which, under the Constitution, the states are sovereign, save only as Congress may constitutionally subtract from their authority, an unexpressed purpose to nullify a state's control over its officers and agents is not lightly to be attributed to Congress." 78 Thus, the Sherman Act, when viewed in terms of its history and purpose, "must be taken to be a prohibition of individual and not state action." "79

While the Parker opinion made little effort to define the scope of the exemption it identified, it did cite two types of activity which would not be protected-Parker would not permit a state to legislate immunity for private violation of the antitrust laws, nor would it permit a state to enter into anticompetitive agreements with private parties. ${ }^{80}$ In particular, Parker did not discuss whether a state could delegate its Parker immunity. This is crucial in the context of a highly regulated area such as the health services industry, because regulations are often formulated by a mixture of official and nonofficial action. For a thirtytwo year period following the Court's decision in Parker, the Supreme Court took no occasion to further clarify the doctrine, ${ }^{81}$ although lower courts had had occasion to apply the broad doctrine in a number of

72. 39 F. Supp. 895 (S.D. Ca. 1941), rev'd, 317 U.S. 341 (1943).

73. 317 U.S. at $350-52$.

74. Id. at 350 .

75. Id. at 359 .

76. Id. at 350 .

77. Id. at $350-51$.

78. Id. at 351 .

79. Id. at 352 .

80. Id. at 351-52.

81. But of. Schwegmann Bros. v. Calvert Distillers Corp., 341 U.S. 384 (1951) (construing Miller-Tydings Act, which exempted certain resale price maintenance agreements from operation of the Sherman Act). 
instances. ${ }^{82}$ In several recent cases, however, the Court has ended its silence and further developed the state action exemption. ${ }^{83}$

The first recent Supreme Court case to present a state action issue was Goldfarb v. Virginia State Bar. ${ }^{84}$ The plaintiffs in that case alleged that the minimum fee schedule promulgated by the Fairfax County Bar Association and enforced by the Virginia State Bar constituted price fixing proscribed by section 1 of the Sherman Act. The State Bar defended by arguing inter alia that its actions were immune from antitrust scrutiny by virtue of Parker state action. In denying the exemption, the Court considered two factors: "state intent"-the Virginia Supreme Court had expressly admonished attorneys not to be bound by fee schedules" - and "state involvement"-the schedules had been formulated by the local bar association, which the Court characterized as a private voluntary organization, at least for the purpose of setting fees. ${ }^{86}$ However, the opinion did not reveal whether either or both of these factors determined whether a practice was exempt. Beyond the statement that, in order for Parker to apply, the "anticompetitive activities must be compelled by direction of the State acting as a sovereign," ${ }^{87}$ the opinion provided little guidance for interpreting Parker.

The second and more important case is Cantor v. Detroit Edison Co ${ }^{88}$ That case involved a challenge to Detroit Edison's light bulb exchange program. Under the program, the utility supplied its residential customers with "free" replacement light bulbs, adding the cost to the overall price its customers paid for electricity. The bulb program was included in the tariff the utility was required to file with the Michigan Public Service Commission. As part of the tariff, the program could not legally be changed without commission approval. The antitrust claim, raised by a druggist who sold electric light bulbs, was that the utility used its monopoly power in the distribution of electricity to restrain competition in the light bulb market. Although six Supreme Court justices agreed that the bulb program was not exempt, ${ }^{89}$ Cantor's

82. For a comprehensive catalogue of cases, see Handler, supra note 21, at 2 n.4. See also Slater, supra note 21, at 91-101; Comment, supra note 21, at 876-95, for the interpretations that developed of the state action exemption and the leading cases.

83. Bates v. State Bar of Ariz., 433 U.S. 350 (1977); Cantor v. Detroit Edison Co., 428 U.S. 579 (1976); Goldfarb v. Virginia State Bar, 421 U.S. 773 (1975). See City of Lafayette v. Louisiana Power \& Light Co., 98 S. Ct. 1123 (1978). See note 133 infra.

84. 421 U.S. 773 (1975).

85. Id. at 789 .

86. Id. at 790 .

87. Id. at 791 .

88. 428 U.S. 579 (1976).

89. Justices Stevens, Brennan, White, Marshall, Blackmun and Chief Justice Burger concurred in the result. 
four opinions left a good deal of confusion as to the scope of the state action exemption..$^{90}$

A majority of five-Chief Justice Burger and Justices Stevens, Brennan, White and Marshall-agreed on two things the exemption did not cover. In an opinion by Justice Stevens, they considered two possible defenses, and, without endorsing either one, held that neither was available to Detroit Edison. First, the utility had contended that any activity compelled by the state was exempt from the antitrust laws. ${ }^{91}$ Presuming that there was a defense based solely on "compulsion," the Court stated that it would not be available unless "the State's participation in a decision is so dominant that it would be unfair to hold a private party responsible for his conduct implementing it."92 Justice Stevens contended that Detroit Edison did not qualify for exemption under this theory because the decision whether to have such a program rested primarily with the utility, not the state agency. ${ }^{93}$ Thus, "notwithstanding the state participation in the decision, the private party exercised sufficient freedom of choice" to warrant a conclusion that it "should be held responsible for the consequences of [its] decisions." 94

The utility's second theory was that "the essential teaching of Parker v. Brown is that the federal antitrust laws should not be applied in areas of the economy pervasively regulated by state agencies."95 The Court rejected this formulation, suggesting instead a two-step inquiry. First, is the antitrust exemption "necessary in order to make the regulatory Act work?"96 Second, does the regulation in question go beyond the "minimum extent necessary"97 to achieve its objective? In the Court's view, the light bulb program was an extension of the utility's franchise into the "essentially unregulated" market for light bulbs.98 The Court reasoned that there was little to connect the program to the state's "interest in regulating its utilities" distribution of electricity." 99

90. Justice Stevens wrote the opinion of the Court and was joined by Justices Brennan, White and Marshall. 428 U.S. at 581. Chief Justice Burger concurred in parts I and III of the Stevens opinion and filed his own concurring opinion. Id. at 603 . Justice Blackmun filed an opinion concurring in the judgment, $i d$. at 605 , and Justice Stewart wrote a dissent. Id. at 614 .

91. Id. at 592 .

92. Id. at 594-95.

93. Id. at 594.

94. Id. at 593 .

95. Id. at 595 .

96. Id. at 597 .

97. Id. (quoting Otter Tail Power Co. v. United States, 410 U.S. 366, 391 (1973)).

98. 428 U.S. at 595 .

99. Id. at 598 . 
Another portion of the Stevens opinion, in which only Justices White, Brennan and Marshall joined, suggested that there might be no "state regulation" defense for private defendants at all. ${ }^{100}$ Justice Stevens noted that the Supreme Court "has never sustained a claim that otherwise unlawful private conduct is exempt from the antitrust laws because it was permitted or required by state law," 101 and he argued that Parker controlled only cases involving suits against state officials in their official capacities. ${ }^{102}$

The plurality took particular notice of the amicus curiae position of the United States in Parker where the government had espoused the view that there was

an important distinction between economic action taken by the State itself and private action taken pursuant to a state statute permitting or requiring individuals to engage in conduct prohibited by the Sherman Act. The Solicitor General contended that the private conduct would clearly be illegal but recognized that a different problem existed with respect to the State itself. ${ }^{103}$

Justice Stevens acknowledged that "the term 'state action' may be used broadly to encompass individual action supported to some extent by state law or custom," 104 but argued that "[s]uch a broad use of the term . . . is not ... what Mr. Chief Justice Stone described in his Parker opinion." ${ }^{105}$ In each of thirteen references to state action in Parker

his language was carefully chosen to apply only to official action, as opposed to private action approved, supported, or even directed by the State. ...

The cumulative effect of these carefully drafted references unequivocally differentiates between official action, on the one hand, and individual action (even when commanded by the state), on the other hand. ${ }^{106}$

Justice Stevens concluded that "[s]ince the case . . does not call into question the legality of any act of the State of Michigan or any of its officials or agents, it is not controlled by the Parker decision." 107

Under the interpretation of the plurality, Parker might be construed as only a procedural limitation - a plaintiff might be able to circumvent Parker simply by suing an appropriate defendant. The

100. Id. at $585-92$ (Part II, not concurred in by Burger, C.J.).

101. Id. at 600 .

102. Id. at 591 .

103. Id. at $588-89$ (footnote omitted).

104. Id. at 590 .

105. Id. at 590-91.

106. Id. at 591 n.24.

107. Id. at 591-92. 
plurality actually suggested this line of inquiry: "What sort of charge might have been made against the various private persons [in Parker] who engaged in a variety of different activities implementing that program is unknown and unknowable because no such charges were made." ${ }^{108}$ This reading of Cantor would suggest that the state action exemption is available only to a state and its officials (and perhaps certain of its subdivisions) although immunity would not automatically be conferred on all governmental agencies or units. ${ }^{109}$

The remaining five justices all advocated a more substantive interpretation of Parker. The three dissenters, Stewart, Powell and Rehnquist, would have exempted all state-compelled activity, even when the impetus for governmental compulsion was essentially self-initiated. ${ }^{110}$ Chief Justice Burger, on the other hand, who was troubled by focusing exclusively on the identity of the party defendant, argued simply that Parker must have some substantive effect, without suggesting which activities should be protected. ${ }^{111}$ Only Justice Blackmun suggested a formula for separating exempted and nonexempted activity. He rejected the distinction between state-mandated and state-authorized conduct as too facile. ${ }^{112}$ While Goldfarb established state compulsion as a prerequisite to immunity-a necessary precondition-it did not hold that a state requirement, by itself, was sufficient to warrant immunity. ${ }^{113}$ Justice Blackmun also found illusory a test that relied on who initiated the conduct; the degree of private initiation should not be determinative. ${ }^{114}$ Finally, Justice Blackmun rejected any test dependent on the affirmative articulation by the state that the questioned conduct was consciously sanctioned as a part of its regulatory scheme, although he acknowledged that to be "a tempting solution, particularly in this case, where there is little to suggest . . . that the Michigan Public Service Commission has even actively considered the light-bulb tie-in, much less articulated a justification for it." 115 Rather, Justice Blackmun proposed a rule of reason approach: "state-sanctioned anticompetitive activity must fall like any other if its potential harms outweigh its benefits." 116 He would have balanced the "implicated federal and state in-

108. Id. at 601 .

109. See City of Lafayette v. Louisiana Power \& Light Co., 98 S. Ct. 1123 (1978). See note 133 infra. But see Verkuil, supra note 21, at 331 n.15, 348 n.109.

110. 428 U.S. at 626.

111. Id. at 604 .

112. Id. at 609 .

113. Id.

114. Id. at 609-10.

115. Id. at 610 .

116. Id. 
terests with a view to assuring that when these are truly in conflict, the former prevail." 117 As Justice Blackman indicated, the balancing of state and federal interests is a common part of commerce clause analysis $^{118}$ - an area in which the Court has been particularly active in recent years. ${ }^{119}$

It seems obvious that the various opinions in Cantor blur the contours of the state action exemption. Unfortunately, little comfort may be taken from the Court's unanimous opinion in Bates v. State Bar of Arizona. ${ }^{120}$ Appellant attorneys were charged by the state bar with violation of the state supreme court's disciplinary rule that prohibited attorneys from advertising. The Arizona Supreme Court upheld the disciplinary action and rejected the appellants' claim that the rule violated sections 1 and 2 of the Sherman Act. ${ }^{121}$ While a bare majority found that the disciplinary rule in question violated the commercial speech protections of the first amendment, ${ }^{122}$ the Court was unanimous in holding that the restraint upon attorney advertising imposed by the Supreme Court of Arizona was not subject to attack under the Sherman Act.

In upholding the state action exemption, the Court quickly distinguished Goldfarb as a case where the state had not required the anticompetitive activities of respondents, whereas in Bates the challenged restraint was an affirmative command of the Arizona Supreme Court. ${ }^{123}$ This reaffirmed the position articulated in Cantor that state compulsion is a necessary, if not sufficient, condition for the application of the state action exemption.

Cantor posed further problems. The appellants attempted to rely on that segment of the Cantor opinion that emphasized the question of who originated or conceived of the anticompetitive conduct, arguing that the disciplinary rule at issue was derived from and originated by the organized bar, which had succeeded in having its proposal adopted by the state supreme court. ${ }^{124}$ The Court very cryptically rejected the

117. Id. at 611 .

118. Id. at 612 .

119. See, e.g., Hunt v. Washington State Apple Advertising Comm'n, 432 U.S. 333 (1977); Great Atlantic \& Pacific Tea Co. v. Cottrell, 424 U.S. 366 (1976); Pike v. Bruce Church, Inc., 397 U.S. 137 (1970). See generally Blumstein, supra note 66.

120. 433 U.S. 350 (1977). (1977)

121. In re Bates, 113 Ariz. 394, 555 P.2d 640 (1976), aff $d$ in part, rev'd in part, 433 U.S. 350

122. Justices Rehnquist, Powell, Stewart and Chief Justice Burger all dissented from the conclusion that the rule in question violated the first amendment.

123. 433 U.S. at $359-60$.

124. Id. at 360 . 
analogy, stating "that the context in which Cantor arose is critical."12s Presumably, the difference between Bates and Cantor is that in Cantor the utility claimed that to hold it liable for following a state-imposed requirement would be unfair, while in Bates the attorneys were not observing, but were charged with violating, the state-imposed regulation. Thus, the contexts were indeed quite different. The appellants in Bates were not seeking to charge the bar association with an antitrust violation; as a defense to a state-run disciplinary proceeding, the fairness concerns underlying the entire analysis of this point in Cantor disappear.

While one can accept the distinction of Cantor on the degree of private initiation point, the other grounds of distinction reflect an obvious compromise among the various themes present in Cantor. Justice Blackmun, who did not participate in any of the Cantor opinions other than his own, merely listed three distinguishing factors that were important to various coalitions in Cantor. Interestingly, the first factor listed was the identity of the parties, a point stressed by the Cantor plurality: "Cantor would have been an entirely different case if the claim had been directed against a public official or public agency, rather than against a private party." 126 In Bates, however, the appellants' claims were directed against the state since the Arizona Supreme Court was the "real party in interest." 127

The second distinction mentioned in Bates was that in Cantor "the State had no independent regulatory interest in the market for light bulbs",;28 in Bates, on the other hand, "the regulation of the activities of the bar is at the core of the State's power to protect the public." 129 Six of the justices in Cantor would accept this as an important element in a state action exemption analysis. ${ }^{130}$ Similarly, it is likely that five justices from Cantor would have accepted the final distinction drawn in Bates, namely, that "the light-bulb program in Cantor was instigated by the utility with only the acquiescence of the state regulatory commission," 131 while there was a "clear articulation of the State's

125. Id. at 361 .

126. Id. In a most studiedly neutral and detached manner, Justice Blackmun observed in a footnote that this factor was important for four justices in Cantor, while the three dissenters "would have applied the state-action exemption regardless of the identity of the defendants." Id. at $361 \mathrm{n} .13$.

127. Id. at 361 .

128. Id.

129. Id.

130. See 428 U.S. at 584-85 (Stevens, J.) (joined by Justices Brennan, Marshall and White); id. at 604-05 (Burger, C.J.); id. at 612-14 (Blackmun, J.).

131. 433 U.S. at 362 . See 428 U.S. at 592 (Stevens, J.) (joined by Justices Brennan, Marshall and White). The Chief Justice concurred on this point. Id. at 603 . 
policy with regard to professional behavior" 132 in Bates. In sum, the Court felt that where "the state policy is so clearly and affirmatively expressed and ... the State's supervision is so active," there is a reduced risk "that federal policy is being unnecessarily and inappropriately subordinated to state policy."133

132. 433 U.S. at 362.

133. Id. A fourth significant case, City of Lafayette v. Louisiana Power \& Light Co., $98 \mathrm{~S}$. Ct. 1123 (1978), was handed down after the completion of this Article. City of Lafayette involved the question whether alleged anticompetitive activities of city-owned and -operated electric utilities were exempt from antitrust coverage under Parker $v$. Brown. A bare majority of five agreed that the utilities' status as city utilities did not automatically entitle them to a Parker exemption. However, there was disagreement as to the framework of analysis for considering Parker exemptions in this context and as to what standards the lower courts should use to decide whether a particular activity was exempt.

Justice Brennan, joined by Justices Marshall, Powell and Stevens, relied on the "official action" reading of Parker. This exemption, according to the Brennan opinion, does not necessarily extend to municipalities, although "actions of municipalities may reflect state policy." Id. at 1137 . The opinion suggested a lower court inquiry directed at determining whether the utilities acted as agents of the state in performing any of the challenged activities. An activity would be exempt if it were "found "from the authority given a governmental entity to operate in a particular area, that the [state] legislature contemplated the kind of action complained of." "Id. at 1138 (quoting City of Lafayette v. Louisiana Power \& Light Co., 532 F.2d 431, 434 (5th Cir. 1976)).

Chief Justice Burger, in his concurrence, agreed that there was no automatic exemption for city utilities, but for different reasons. As he had in Cantor, the Chief Justice asserted that Parker protected activities, not parties. $98 \mathrm{~S}$. Ct. at 1140 . He noted that the municipality's participation in the business of supplying electricity was "proprietary," rather than governmental, id. at 1141, and argued that "[t]here is nothing in Parker $\nu$. Brown, or its progeny, which suggests that a proprietary enterprise with the inherent capacity for economically disruptive anticompetitive effects should be exempt from the Sherman Act merely because it is organized under state law as a municipality." Id. at 1139 . For the Chief Justice, the case involved nothing more than "an ordinary dispute among competitors in the same market." Id. at 1140 . Therefore, he urged that the city utility be treated in the same manner as a private one. In that posture, the case should be governed by the "strict necessity" rationale of Cantor, since "the issue . . . is whether the Sherman Act reaches the proprietary enterprises of municipalities." Id. at 1141 (footnote omitted). Thus, the Chief Justice declined to address the question of the extent to which "the Sherman Act impinges generally upon the monopoly powers of state and local governments." Id. Given the essentially private, competitive nature of the city's activities, Chief Justice Burger argued that the issue discussed by the plurality and the dissent was not actually presented by the case. Id.

Justice Marshall's brief concurring opinion was somewhat puzzling. While he joined in the Brennan opinion, he did so on the understanding that the test that the plurality advocated incorporated Chief Justice Burger's strict "minimum extent necessary" standard. Id. at 1139 . He argued that an activity would not be an "act of government" within the meaning of the plurality opinion unless it were no "more anticompetitive ... than necessary to effectuate governmental purposes." Id.

The four dissenters in City of Lafayette-Justices Stewart, Rehnquist, White and Blackmun-argued that Parker exempted the cities' acts. "The petitioners are governmental bodies, not private persons, and their actions are 'act[s] of government' which Parker v. Brown held are not subject to the Sherman Act." Id. at 1144. For the dissenters, "[t]he fundamental error in the opinions of the plurality and of the Chief Justice is their failure to recognize the difference between private activities authorized or regulated by government on the one hand, and the actions of government itself on the other." $I d$.

Of course, as the Chief Justice recognized, the plurality and the dissent split sharply on the 
The recent Supreme Court cases clearly have created some confusion. Aside from the "fairness" defense suggested by the Cantor majority, there remain two distinct approaches to the state action exemption, one largely procedural and the other more substantive. It is impossible to discern a holding that either one or both of these approaches is correct.

consequences that arise from governmental action by political subdivisions of a state. The plurality was unwilling to extend the Parker exemption automatically to political subdivisions without assurance that "the State authorized or directed a given municipality to act as it did." Id. at 1137. The dissent thought Parker should exempt all governmental action. "The distinction established in Parker v. Brown was not one between actions of a state legislature and those of other governmental units. Rather, the Court drew the line between private action and governmental action." Id. at 1145. For the dissent, therefore, cities are governmental for purposes of Parker, and immunity should follow inexorably. According to the City of Lafayette dissenters, the compulsion requirement of Goldfarb was irrelevant because no actions of private parties were implicated. Id. at $1146-47$.

By joining the dissent in City of Lafayette, Justice Blackmun, who had suggested a balancing approach in his Cantor concurrence, indicated that the balancing formula apparently applied only in cases involving private parties. He agreed with Justice Stewart that municipalities should enjoy Parker exemption, but reserved judgment on the question whether "petitioners should be immune under the Sherman Act even if found to have been acting in concert with private parties." Id. at 1151 .

The line-up of the justices in City of Lafayette is somewhat puzzling; Justice White joined the dissent, whereas he had been in the plurality in Cantor, and Justice Powell joined the plurality, whereas he had been a dissenter in Cantor. Perhaps the switch on the part of these two justices can be explained by the different issues raised in the two cases. In Cantor, Justice White accepted the "official conduct" analysis of the plurality as a limitation on Parker immunity. His position in City of Lafayette suggests that he would extend the exemption to official acts of political subdivisions, but that he still would not extend the exemption to nongovernmental defendants. As will be discussed in the next section, see text accompanying notes 142-67 infra, his position in Cantor seems to rely on an eleventh amendment view of the Parker doctrine. To be consistent, he would have to conclude that Parker should be broader than a traditional eleventh amendment analysis, covering all political subdivisions automatically. Nevertheless, Justice White's adherence to all of Justice Stewart's dissent in City of Lafayette is puzzling.

Justice Powell's position in the plurality in City of Lafayette is also worthy of discussion. Perhaps Justice Powell, alone among the justices, sees Parker as a doctrine that stems from both tenth and eleventh amendment sources, a position developed later in this Article. See text accompanying notes 142-242 infra. In the context of conferring Parker immunity on private parties, he would apply a tenth amendment approach, limited by Goldfarb's requirement that immunity arise only where government compels private anticompetitive conduct. $I d$. at 1136-37. In the context of determining which governmental units receive Parker immunity, however, perhaps he sees the issue as parallel to eleventh amendment analysis. In that way, he is able to join the plurality's essentially eleventh amendment, sovereign immunity approach in City of Lafayette. The importance of this distinction is hinted at in a footnote to the plurality's opinion:

Cantor's analysis is not, however, necessarily applicable here. Cantor was concerned with whether anticompetitive activity in which purely private parties engaged could, under the circumstances of that case, be insulated from antitrust enforcement. The situation involved here, on the other hand, presents the issue of under what circumstances a State's subdivisions engaging in anticompetitive activities should be deemed to be acting as an agent of the State.

Id. at 1136 n.40. It would seem that that footnote provides an insight into explaining Justice Powell's switch in vote from Cantor to City of Lafayette. 
The Cantor majority's suggestion of the two-part test of "necessity" for areas of regulation that are protected may provide an important insight, however. The majority derived this test from cases in which the issue was whether Congress had implicitly repealed part of the antitrust laws by a subsequent regulatory enactment. ${ }^{134}$ Use of this test in the context of state regulation suggests that the states have some power to immunize their acts from the federal antitrust laws. But, as the dissent pointed out, in view of the supremacy clause, "[i]mplied repeal' of federal antitrust laws by inconsistent state regulatory statutes is not only 'not favored' . . . it is impossible."135 However, some explanation for and clarification of the Parker v. Brown doctrine can be found in the tenth and eleventh amendments to the Constitution. Throughout Cantor there are references to state sovereignty and the role of the states in the federal system. ${ }^{136}$ Both the eleventh amendment's grant of state sovereign immunity and the tenth amendment's reservation of powers to the states play important parts in defining the states' status.

These constitutional principles are useful in determining an appropriate balance of state and federal policies in Parker v. Brown situations. Indeed, the constitutional underpinnings were not very far from the surface in Parker itself when the Court noted that it would not lightly infer a congressional intent to "nullify a state's control over its officers and agents" in a federal system where "the states are sovereign." 137 Moreover, constitutional developments in tenth and eleventh amendment federalism doctrine indicate that there are circumstances in which Congress, even if it expressed its views explicitly, might be unable to substitute its chosen economic measure (antitrust) for the system adopted by the states in the exercise of their police power. ${ }^{138}$ The test of necessity set forth in Cantor becomes much less puzzling if seen in the broader constitutional context. While under the supremacy

134. 428 U.S. at $596-97 \&$ n.36.

135. Id. at 629 (Stewart, J., dissenting) (quoting 428 U.S. at 597-98 n.37).

136. E.g., 428 U.S. at 632, 637 (Stewart, J., dissenting).

137. 317 U.S. at 351.

138. See, e.g., National League of Cities v. Usery, 426 U.S. 833 (1976); Edelman v. Jordan, 415 U.S. 651 (1974). There is a difference between relying on constitutionally based concerns of federalism and relying on a tenth amendment analysis. For example, in Bates the Court used constitutionally based values of federalism in concluding that federal law did not preempt the state regulation in those circumstances. However, if Congress were to clarify its intent, indicating explicitly that the Arizona Supreme Court action challenged in Bates was to be included within the coverage of federal antitrust law, the sole issue would be whether Congress could go that far under the tenth amendment in light of National League of Cities v. Usery, 426 U.S. 833 (1976). Cf. Cantor, 428 U.S. at 605 (Blackmun, J., concurring) ("[n]o one denies that Congress could, if it wishes, override those state laws whose operation would subvert the federal policy of free competition in interstate commerce"). 
clause a state certainly cannot repeal a federal law, tenth and eleventh amendment concerns for state autonomy might suggest an interpretation of federal law that is sensitive to these values.

In any event, after Cantor it seems that at least six justices on the Court now feel that it is inappropriate to rely exclusively on the legislative intent of Congress when it passed the Sherman Act, ${ }^{139}$ in view of the vast expansion of federal power that has occurred since then. ${ }^{140}$ Rather, it seems that the Court is (and should be) relying on more general, constitutionally derived principles of federalism to strike a balance between federal and state interests. ${ }^{141}$ This suggests that the different interpretations of Parker reflect the justices' individual perceptions of the source and scope of constitutional limitations on the reach of the antitrust laws. We now turn to a discussion of those constitutional principles.

\section{The Relevance of Constitutional Principles of Federalism IN Determining the Contours of THE PARKER V. BROWN EXEMPTION}

\section{A. Eleventh Amendment Principles and Their Application.}

Justice Stevens, in his plurality opinion in Cantor, suggested that the Court, in setting Parker v. Brown for reargument, was concerned about the impact of its contemporaneous decision in Georgia $v$. Evans, ${ }^{142}$ which had held a state to be a "person" within the Sherman Act and therefore entitled to maintain an action for treble damages. Justice Stevens noted that after Georgia v. Evans the Court was "[p]resumably . . . then concerned with the relationship between the sovereign States and the antitrust laws." 143 The holding that a state could sue under the Sherman Act generated the logical next question-whether a state could in turn be sued and held liable for damages. With the question phrased in this manner, it seems that the answer must necessarily entail consideration of the notions of federalism embodied in the eleventh amendment. The eleventh amendment limits the susceptibility of states to suit in federal courts; ${ }^{144}$ subjecting a state or its officials acting in their official capacities-the situation in

139. Cantor, 428 U.S. at 606 (Blackmun, J., concurring).

140. See Hospital Bldg. Co. v. Rex Hosp. Trustees, 425 U.S. 738, 743 n.2 (1976), and cases cited therein.

141. See text accompanying notes $35-40,67-68$ supra.

142. 316 U.S. 159 (1942).

143. 428 U.S. at 587.

144. U.S. ConST. amend. XI provides: "The judicial power of the United States shall not be construed to extend to any suit in law or equity, commenced or prosecuted against one of the United States by Citizens of another State, or by Citizens or Subjects of any Foreign State." 
Parker v. Brown - to antitrust liability would seem to conflict with the policy embodied by the eleventh amendment. ${ }^{145}$ This suggests that eleventh amendment concerns were an important-even major-source for the Parker doctrine's development.

Treating Parker v. Brown as a doctrine influenced by eleventh amendment federalism concerns has the interesting consequence of making the plurality opinion in Cantor conceptually understandable. Justice Stevens' opinion in Cantor, much criticized by the dissenters ${ }^{146}$ and Chief Justice Burger, ${ }^{147}$ stressed the importance of the identity of the party defendants in a Parker v. Brown setting. ${ }^{148}$ The plurality argued that since no public officials were being sued, no act of the sovereign was being challenged: "Since the case before us does not call into question the legality of any act of the State . . . or any of its officials or agents, it is not controlled by the Parker decision." 149 If Justice Stevens' understanding of the Parker $v$. Brown doctrine has its intellectual roots in the eleventh amendment's concern about litigation against a sovereign state and its officials, the focus on the identity of the parties becomes not only understandable but also crucial to determining how such a case ought to be decided. ${ }^{150}$

145. See Edelman v. Jordan, 415 U.S. 651 (1974). See also Hutto v. Finney, 98 S.Ct. 2565 (1978).

146. 428 U.S. at 616 (the plurality opinion "would trivialize [Parker v. Brown] to the point of overruling it"); $i d$. at $616 \mathrm{n} .4$ ("[i]f Parker v. Brown . . could be circumvented by the simple expedient of suing the private party against whom the State's 'anticompetitive' command runs, then that holding would become an empty formalism, standing for little more than the proposition that Porter Brown sued the wrong parties").

147. 428 U.S. at 603-04.

148. Id. at 591 .

149. Id. at $591-92$.

150. The significance of the identity of the parties is illustrated by the very recent decision in City of Lafayette v. Louisiana Power \& Light Co., 98 S. Ct. 1123 (1978) which was handed down after this Article had been completed. There, the Court rejected the argument that cities were necessarily entitled to a Parker exemption; rather, it remanded for a determination as to whether the city acted "pursuant 'to the state['s] command." " 98 S. Ct. at 1137 (quoting Parker, 317 U.S. at 352). It is well established that political subdivisions of states do not as such enjoy automatic eleventh amendment protection. Traditional eleventh amendment analysis inquires into whether the political subdivision is so closely connected with the state that it might properly be viewed as an agent of the state and therefore entitled to state immunity. See Mt. Healthy City School Dist. Bd. of Educ. v. Doyle, 429 U.S. 274, 280 (1977). The plurality recognized this point and cited eleventh amendment cases. $98 \mathrm{~S}$. Ct. at 1136 . In fact, they were chastised by the dissent for their "reliance . . . on the basically irrelevant body of law under the Eleventh Amendment." Id. at 1146. See id. at 1136-37 n.42. Furthermore, the eleventh amendment approach is consistent with the Court's earlier decision in Schwegmann Bros. v. Calvert Distillers Corp., 341 U.S. 384 (1951), where both parties were private, not governmental. In that case, a distributor sought to enforce the terms of a state law against a retailer, so as to secure conformity to a resale price maintenance agreement negotiated between the distributor and other retailers. The Court declined to grant an antitrust exemption to this arrangement. Under the eleventh amendment approach, the Schwegmann outcome is explainable as reflecting an unwillingness to allow a state to confer its 
By justifying an analytical focus on the identity of the parties, the eleventh amendment approach provides a rationale for declining to extend Parker immunity to private parties. If subunits of government do not enjoy the state's eleventh amendment immunity, ${ }^{151}$ there is no reason to require inclusion of private persons acting under color of state law within the exempt category. Indeed, only in Parker and Bates has the Supreme Court sustained the so-called Parker defense, and in both cases the defendants or real parties in interest were state officials. ${ }^{152}$ Thus, the position of the plurality in Cantor conforms neatly to existing Supreme Court decisional law.

The eleventh amendment approach of accommodating federal interests with federalistic concerns for the quasi-sovereign nature of state governments also accords neatly with the language in Parker itself. Chief Justice Stone concluded that the legislative history of the Sherman Act did not suggest a purpose "to restrain a state or its officers or agents from activities directed by its legislature." 153 Then, in language reminiscent of recent eleventh amendment cases, he said: "In a dual system of government in which, under the Constitution, the states are sovereign, save only as Congress may constitutionally subtract from their authority, an unexpressed purpose to nullify a state's control over its officers and agents is not lightly to be attributed to Congress." 154 This deference to principles of state sovereignty, which permeates the Parker opinion, was described by Justice Stevens in his Cantor opinion as reflecting an emphasis on the parties involved ${ }^{155}$-implicitly an eleventh amendment approach. As Justice Stevens concluded, "[t]he cumulative effect of these carefully drafted references [in Parker] unequivocally differentiates between official action, on the one hand, and individual action (even when commanded by the state), on the other hand." 156

immunity on the conduct of private parties-even where the operation of state law purported to be mandatory on the private parties.

151. See, e.g., Mt. Healthy City School Dist. Bd. of Educ. v. Doyle, 429 U.S. 274 (1977);

Edelman v. Jordan, 415 U.S. 651, 667 n.12 (1974); Lincoln County v. Luning, 133 U.S. 529 (1890).

152. See 433 U.S. at $361 \&$ n.13.

153. 317 U.S. at $350-51$.

154. Id. at 351. See Employees v. Department of Pub. Health \& Welfare, 411 U.S. 279, 28485 (1973).

155. 428 U.S. at 591 n.24.

156. Id. In addition to the careful textual references in Parker-emphasized by Justice Stevens for a four-member plurality in Cantor-there is one other piece of contemporaneous evidence that bolsters the plausibility of basing Parker on a preemption foundation derived from eleventh amendment principles of sovereign immunity. Less than two years prior to the decision in Parker, Justice Stone wrote the opinion in United States v. Darby, 312 U.S. 100 (1941), which sustained the constitutionality under the commerce clause of the minimum wage and maximum hour provisions of the Fair Labor Standards Act of 1938. In Darby, the Court rejected a chal- 
This analysis is not meant to suggest that the Parker doctrine is coextensive with the eleventh amendment. It is clear, for example, after Edelman v. Jordan ${ }^{157}$ that suits for injunctive relief are not barred by the eleventh amendment. ${ }^{158}$ If the Parker doctrine had no independent force beyond the narrow limits of the eleventh amendment then the decisions in Bates and Parker themselves would have been incorrect because in neither case was the plaintiff seeking damages from the state. Therefore, while the Parker doctrine is built in part on the same concerns of federalism that underlie the eleventh amendment, that doctrine certainly goes further than the requirements of the Constitution.

By treating the state action exemption as a nonconstitutional doctrine, the Court has avoided two difficult constitutional questions-whether Congress, relying on its commerce clause power, could constitutionally eliminate state sovereign immunity in antitrust cases, as well as the related question of whether that was Congress' intent. In

lenge bottomed on the tenth amendment as an independent limitation on federal power. Justice Stone noted that "[t]he amendment states but a truism that all is retained which has not been surrendered." Id. at 124. For years the "truism" language of Darby was construed as ending consideration of the tenth amendment as an affirmative limitation on federal power, so it is reasonable to infer that the federalism principles embodied in Parker-as highlighted by the Stevens plurality opinion in Cantor-are derived from eleventh amendment principles.

157. 415 U.S. 651 (1974). In Edelman, Illinois had illegally withheld welfare benefits from eligible beneficiaries. These beneficiaries then sought to obtain a damage award for the impermissibly withheld funds. The Court held that although such a damage remedy would violate the eleventh amendment and was therefore barred, the suit for prospective relief was permissible under the eleventh amendment. Id. at 665-71. See L. TRIBE § 3-36.

158. See 415 U.S. at 664 . Further, eleventh amendment cases permit federal intervention to enforce statutes. Employees v. Department of Pub. Health \& Welfare, 411 U.S. 279 (1973), is illustrative. Although the federal Fair Labor Standards Act (FLSA) had been amended explicitly to cover state hospitals and schools, the Employees Court ruled that private plaintiffis were prohibited by the eleventh amendment from enforcing their statutory entitlements against the state in federal court. Nevertheless, the Court simultaneously indicated that the Secretary of Labor had authority to sue to enjoin further state violations and even to collect back wages on behalf of aggrieved workers. The eleventh amendment apparently posed no barrier to such federal action. Id. at 285-86. See Monaco v. Mississippi, 292 U.S. 313, 328-29 (1934).

Some commentators have suggested that Parker's result can be in part justified by the congruence of federal agriculture policy with that of the state of California. See, e.g., Slater, supra note 21, at 86-87. Where the federal government initiates an antitrust enforcement action against a state, that would be a manifest expression of conflict between federal and state policies by the executive branch. Under those circumstances, it might be appropriate on policy as well as eleventh amendment grounds to allow the suit to proceed. This, indeed, was implicitly the Court's thinking in Employees, when it noted that the ability of the Secretary of Labor to sue was a safeguard of federal enforcement interests of the FLSA. 411 U.S. at 286.

The implications of this analysis for federal antitrust enforcement efforts are self-evident; an eleventh amendment approach would authorize federal enforcement in areas otherwise arguably immune under Parker v. Brown. For a very recent example of a successful federal antitrust action against a state regulatory board, see United States v. Texas State Bd. of Pub. Accountancy, Civ. No. A-76-CA-219 (W.D. Tex. May 5, 1978). 
the 1976 case of Fitzpatrick v. Bitzer ${ }^{159}$ the Court held that Congress did have the power to limit state sovereign immunity. However, the majority opinion carefully noted that the legislation that defeated sovereign immunity was an exercise of power pursuant to section 5 of the fourteenth amendment, suggesting that Congress might not be able to do the same thing under the commerce clause or other Article I powers. ${ }^{160}$ It should be noted, however, even if it is concluded that Congress could abridge state sovereign immunity, that the Court has been very reluctant to imply such an intent on the part of Congress.

As the Court indicated in Employees v. Department of Public Health and Welfare, ${ }^{161}$ it would not presume, without clear evidence, that Congress "desired silently to deprive the States of an immunity they have long enjoyed under another part of the Constitution."162 Similarly, in Fitzpatrick the Court noted that evidence of "congressional intent to abrogate the immunity conferred by the Eleventh Amendment" was "clearly present." ${ }^{163}$ In the antitrust area, some commentators have urged ${ }^{164}$ _and the Court in Parker stated ${ }^{165}$ - that an important element in establishing some realm of state action antitrust immunity is the lack of explicitness in the federal legislation as to its intended effect on state entities as such. Therefore, deference to state sovereignty in the case of the antitrust laws is quite consistent with general eleventh amendment jurisprudence. Moreover, by inviting Congress to make explicit any decision to impose its policy choice on unconsenting states, this formulation of the Parker principle allows for

159. 427 U.S. 445 (1976).

160. Id. at 456. Accord, Hutto v. Finney, 98 S. Ct. 2565, 2575-76, 2578 n.31 (1978). But see id. at 2579 (Brennan, J., concurring).

161. 411 U.S. 279 (1973).

162. Id. at 285. See L. TRIBE \$\$ 3-36, 3-37.

163. 427 U.S. at 451-52. In Hutto v. Finney, 98 S. Ct. 2565 (1978), a 5-4 majority of the Court upheld the Federal Civil Rights Attorney's Fees Awards Act of 1976, Pub. L. No. $94-559$ (to be codified in 42 U.S.C. § 1988). For the court, Justice Stevens ruled that Congress could allow litigants to recover attorney's fees from states despite the eleventh amendment. The majority concluded that "Congress undoubtedly intended to ... authorize fee awards payable by the States when their officials are sued in their official capacities." $98 \mathrm{~S}$. Ct. at 2575. The Court rejected the state's argument that "the statute itself must expressly abrogate the States' immunity," $i d$. at 2578 n.31, but nevertheless adhered to a requirement that Congress' intent be "plain." Id. at 2575 . What divided the majority and the dissent in Hutto was whether the statute itself had to contain express language in order to abrogate a state's eleventh amendment immunity. The dissent would have required "an express statutory waiver of the States' immunity." Id. at 2581 (Powell, J., dissenting). The members of the majority were satisfied that "Congress' intent was expressed in deeds as well as words," $i d$. at 2576 , despite the absence of specific language in the statute itself.

164. See, e.g., Handler, supra note 21, at 14-15; Verkuil, Preemption of State Law by the Federal Trade Commission, 1976 Duke L.J. 225, 240-43; Note, Parker v. Brown: A Preemption Analysis, 84 Y ALE L.J. 1164 (1975).

165. 317 U.S. at 351. 
subsequent consideration of the permissible scope of federal intrusion on state prerogatives under a tenth amendment analysis, where a "suffciently 'drastic invasion of state sovereignty' could be invalidated notwithstanding even the clearest possible expression of congressional purpose."166

However, given Cantor, it is unlikely that a majority of justices would accept the view that the state action exemption is only what has been described as a procedural limitation. ${ }^{167}$ This suggests that Cantor be read as creating two exemptions: the plurality's sovereign immunity approach and the more substantive exemption which is adopted in the majority portion of the Stevens opinion. It is to the second aspect of the exemption that this Article will now turn.

\section{B. Tenth Amendment Principles and Their Application.}

The eleventh amendment approach serves to undergird the analytical foundations of the Stevens plurality opinion in Cantor. However, it is questionable whether, even with a more persuasive analytical framework, the approach of the Cantor plurality will secure a majority as the sole analysis for determining the scope of the Parker exemption. To the contrary, it seems that the Chief Justice ${ }^{168}$ and the Cantor dissenters see Parker as a doctrine whose energizing principle of federalism is rooted in the tenth, not the eleventh, amendment. Justice Blackmun, in his Cantor concurrence, did not address the issue in these terms, but his balancing approach seems to conform rather closely to his position in the recent tenth amendment case of National League of Cities v. Usery. ${ }^{169}$ Interestingly, the Cantor plurality constituted the dissent in Usery, so it is possible to conclude that their attempt to adopt an analysis based on eleventh amendment principles in Cantor reflects an unwillingness to rely on a tenth amendment rubric in developing the Parker doctrine. Court-watching aside, this section will develop an analysis of a tenth amendment approach to the preemption issues involved in Parker situations.

166. L. TRIBE 142 (quoting Fry v. United States, 421 U.S. 542, 547-48 n.7 (1975) (footnotes omitted)).

167. See notes 108-19 supra and accompanying text.

168. See 428 U.S. at 604 (Burger, C.J., concurring).

169. 426 U.S. 833, 856 (1976). Moreover, City of Lafayette confirmed that at least some of the justices were motivated by tenth amendment concerns. In his dissent, Justice Stewart criticized the majority, stating: "[I]f constitutional analogies are to be looked to, a decision much more directly related to this case than those under the Eleventh Amendment is National League of Cities v. Usery . . . $98 \mathrm{~S}$. Ct. at 1146. Justices White, Blackmun and Rehnquist joined in Justice Stewart's dissent. Interestingly, Justice White had been in the plurality in Cantor, while Justice Powell, in the City of Lafayette plurality, was a dissenter in Cantor. See note 133 supra. 
The Cantor dissenters focused on what they perceived as the intent of Congress in 1890 "not to intrude upon the authority of the several states to regulate 'domestic' commerce." 170 They criticized the majority for "simply ignor[ing] the clear evidence of congressional intent and substitut[ing] its own policy judgment about the desirability of disregarding any facet of state regulation that it thinks unwise or of no great importance." 171 However, it seems that the plurality's interpretation of legislative history is distinctly influenced by a constitutional gloss - a concern for values of federalism. ${ }^{172}$ As a matter of statutory interpretation, the Court has now settled that the Sherman Act was intended to extend to the maximum extent of federal power, and the coverage of the Act has expanded "along with expanding notions of congressional power." 173 Thus, as Justice Blackmun has noted, ${ }^{174}$ the problem of accommodating federal antitrust and state regulatory policies was not confronted or addressed by the sponsors of the Sherman Act; they never considered "what was to be the result if the expanding ambit of the Sherman Act should bring it into conflict with inconsistent state law." 175 This means that any limitation on Sherman Act coverage must derive either from a constitutional gloss on interpretation of the statute or from the Constitution itself.

The Cantor dissenters had two closely related objections to a narrowing of Parker. First, such a narrowing would allow for greater intrusion of federal social and economic policy on the ability of states to perform traditional regulatory functions. A more substantive Parker v. Brown doctrine, on the other hand, "performs the salutary function of isolating those areas of state regulation where the State's sovereign interest is, by the State's own judgment, at its strongest, and limits the exemption to those areas." 176 Second, narrowing Parker allows greater scope for judicial interventionism in state regulatory affairs. ${ }^{177}$ Since the language of the Sherman Act is so broad, this

170. 428 U.S. at 632.

171. Id.

172. See Verkuil, supra note 21, at 334: "At the core of the Parker doctrine are higher policies of federalism and judicial economic neutrality which counsel against intervention in state regulatory decisions." See also Slater, supra note 21, at 86: "The real question was and currently is the degree of deference which the federal government should give to the states in the regulation of local affairs."

173. Hospital Bldg. Co. v. Rex Hosp. Trustees, 425 U.S. 738, 743 n.2 (1976).

174. Cantor, 428 U.S. at 605.

175. Id. at 606 . See id. at 632-36 (Stewart, J., dissenting).

176. Id. at 637 .

177. Id. at 640. See Verkuil, supra note 21, at 332-35. Professor Verkuil argues that Parker reflected the Court's unwillingness, having abandoned substantive economic due process, to reimpose judicial restrictions on state regulatory activity under the guise of interpreting the Sherman Act. "One senses the Court realized it was about to walk through a swinging door. 
expansion in scope necessarily allows the Court considerable discretion in reviewing and invalidating state regulatory legislation ${ }^{178}-a$ style of judicial review the dissenters analogized to the role an activist Court played in substantive due process cases. ${ }^{179}$ The dissenters' concern is that "the Court's approach contemplates the selective interdiction of those anticompetitive state regulatory measures that are deemed not 'central' to the limited range of regulatory goals considered 'imperative' by the federal judiciary." 180 Citing to an article by Professor Paul Verkuil, ${ }^{181}$ they criticized the Court's "freewheeling approach" to the command of the Sherman Act, which "create[d] a statutory simulacrum of the substantive due process doctrine" that was "put to rest long ago." 182

These concerns expressed by the Cantor dissenters ${ }^{183}$ seem to reflect the tenth amendment concerns that recently surfaced in Usery, which emphasized the role of the tenth amendment as a limitation on federal power. The tenth amendment ${ }^{184}$ is a general reservation of powers to the states which, in an earlier era, was used as an independent limitation on federal power. ${ }^{185}$ Since 1941, however, it has been widely understood that the tenth amendment requires only that federal

emerging from substantive economic review as a constitutional matter, only to enter it as a statutory matter." Id. 332-33.

178. 428 U.S. at 630.

179. Id. at 627 . See Verkuil, supra note 21, at 333: "With such a broad and vague mandate, the Sherman Act becomes the alter ego of the (economic) due process clause."

180. 428 U.S. at 640 .

181. Id. at $640 \mathrm{n} .28$ (citing Verkuil, supra note 21).

182. 428 U.S. at 640.

183. The Cantor dissenters are clearly hostile to this expansion of federal antitrust coverage since, in effect, it allows "the Congress of 1890 the retroactive benefit of an enlarged judicial conception of the commerce power." $I d$. at 635 . They also recognize that this expansion "was in large part responsible for the advent of the Parker doctrine." Id. Under earlier, restrictive commerce clause interpretations, the kind of accommodation necessary in Parker "would rarely, if ever, have arisen." Id. at 636.

In City of Lafayette, Justice Brennan, writing for the plurality, explicitly joined issue with Justice Stewart on the question whether the Court's role under a regime of narrower Parker immunity can legitimately be analogized to its role in economic substantive due process cases. $98 \mathrm{~S}$. Ct. at $1138 \mathrm{n} .46$.

184. U.S. ConST. amend. X provides: "The powers not delegated to the United States by the Constitution, nor prohibited by it to the States, are reserved to the States respectively, or to the people."

185. See, e.g., Hammer v. Dagenhart, 247 U.S. 251 (1918), which invalidated the federal child labor legislation.

[T] he necessary effect of this act is, by means of a prohibition against the movement in interstate commerce of ordinary commercial commodities, to regulate the hours of labor of children in factories and mines within the States, a purely state authority. Thus the act in a twofold sense is repugnant to the Constitution. It not only transcends the authority delegated to Congress over commerce but also exerts a power as to a purely local matter to which the federal authority does not extend. Id. at 276. 
enactments have a constitutional source. ${ }^{186}$

Usery involved a challenge to Congress' extension of the minimum wage and maximum hour provisions of the federal Fair Labor Standards Act (FLSA) to cover almost all employees of states and their political subdivisions. ${ }^{187}$ In United States v. Darby ${ }^{188}$ the Court had upheld the FLSA as applied to private sector employees and later, in Maryland $v$. Wirtz, ${ }^{189}$ it upheld application of the FLSA to employees of state hospitals, institutions and schools. The decision in Usery overruled Wirtz, ${ }^{190}$ holding that Congress could not legislate minimum wage and maximum hour laws for state and local employees because such laws "impermissibly interfere with the integral governmental functions" of state and local governments. ${ }^{191}$ The Court reasoned that since Congress was displacing decision making authority of sovereign state governments, thereby impairing their "ability to function effectively in a federal system," 192 it was acting beyond its commerce clause authority. ${ }^{193}$

186. See United States v. Darby, 312 U.S. 100, 124 (1941). See note 156 supra.

187. 426 U.S. at 836.

188. 312 U.S. 100 (1941).

189. 392 U.S. 183 (1968).

190. 426 U.S. at $853-55$.

191. Id. at 851. Usery held the federal statute invalid in its application to both state and local governments, $i d$. at $855 \mathrm{n} .20$, thus suggesting that the reach of tenth amendment federalism concerns may exceed that of the eleventh amendment. See note 150 supra and text accompanying notes $151-52$ supra.

192. Id. at 852 (quoting Fry v. United States, 421 U.S. 542, 547 n.7 (1975)).

193. The Usery opinion can be read several ways. See Note, Municipal Bankruptcy, The Tenth Amendment and the New Federalism, 89 HARv. L. Rev. 1871, 1879 n.66 (1976) ("[t]he majority opinion never makes clear whether its holding is grounded in the tenth amendment per se or in federalism restraints implicit in the Constitution as a whole"). Justice Rehnquist at one point stated that "our federal system of government imposes definite limits upon the authority of Congress to regulate the activities of the States as States by means of the commerce power." 426 U.S. at 842. Immediately thereafter he noted, however, that "an express declaration of this limitation is found in the Tenth Amendment." Id. Read in light of the argument that the Court apparently accepted-that there are affirmative limits on the ability of the federal government to act under the commerce clause against states qua states, even though Congress could act vis-a-vis private employers-one plausible view is that Usery rests on a tenth amendment holding.

On the other hand, the Court was careful to narrow the scope of its holding, restricting it to federal exercise of power under the commerce clause. Specifically, the Court noted that it held open the applicability of its Usery analysis to "the scope of Congress' authority under its war power," 426 U.S. at $855 \mathrm{n} .18$, and to other constitutional sources of authority "such as the spending power . . or $\S 5$ of the Fourteenth Amendment." Id. at 852 n.17. Cf. Fitzpatrick v. Bitzer, 427 U.S. 445 (1976) (holding that Congress had authority under $\S 5$ of the fourteenth amendment to abrogate states' immunity conferred by the eleventh amendment). Accord, Hutto v. Finney, 98 S. Ct. 2565 (1978). Moreover, in its final statement of holding, the Court said: "We hold that insofar as the challenged amendments operate to directly displace the States' freedom to structure integral operations in areas of traditional governmental functions, they are not within the authority granted Congress by art. I, \& 8, cl. 3 [the commerce clause]." 426 U.S. at 852. Accord, id. at $856 \mathrm{n} .20$ ("[i]nterference with integral governmental services provided by such subordinate arms 
Usery is significant in this context because of its analytical approach to federal power under the commerce clause. The decision does not challenge the outcome in Darby $y^{194}$ but rather relies on a notion of state sovereignty that serves as a limitation on federal power. Thus, federal commerce clause power which extends to private activities may not be permitted to operate directly on states as states:

We have repeatedly recognized that there are attributes of sovereignty attaching to every state government which may not be impaired by Congress, not because Congress may lack an affirmative grant of legislative authority to reach the matter, but because the Constitution prohibits it from exercising the authority in that manner. ${ }^{195}$

In short, "Congress may not exercise power in a fashion that impairs the States' integrity"196 and "may not abrogate"197 state authority with respect to "functions essential to [their] separate and independent existence." 198

In stating that "there are attributes of sovereignty attaching to every state government which may not be impaired by Congress," 199 the Court in Usery seemed to place great weight on the notion of impairment. The Court was careful to point out the tremendous cost that the FLSA imposes on the states ${ }^{200}$ and noted that the states were left with only two options-to increase revenues or to reduce the number of employees. ${ }^{201}$ The combination of the high cost of compliance and the lack of an acceptable alternative was viewed by Justice Rehnquist as an impermissible impairment. The dissent, in addition to disagreeing with the majority's reading of earlier cases, argued that there was in

of a state government is therefore beyond the reach of congressional power under the Commerce Clause just as if such services were provided by the State itself"). These statements would seem to rely on a structural theory that would restrict the commerce clause as a source of federal power when Congress seeks to legislate against the states as states. This structural analysis might allow the Court to limit the reach of Usery by concluding that similar structural concerns were less applicable to the exercise of other federal powers. See generally Blumstein, supra note 66 .

Under either view, however, it is important for our purposes here to note that the Sherman Act is bottomed on federal commerce clause authority; therefore, the emanations from Usery would be relevant regardless of which theory underlies the Court's decision there.

194. 426 U.S. at $837,840-41$.

195. 426 U.S. at 845.

196. Fry v. United States, 421 U.S. 542,547 n.7 (1975).

197. Usery, 426 U.S. at 846.

198. Id. at 845 (quoting Coyle v. Oklahoma, 221 U.S. 559, 580 (1911)).

199. 426 U.S. at 845.

200. 426 U.S. at 846-47.

201. Id. at 847-48. In Usery, the Court did not rely on the cost factor in reaching its decision: "We do not believe particularized assessments of actual impact are crucial to resolution of the issue presented, however." Id. at 851 . Nevertheless, Justice Rehnquist was clearly influenced by the imposition of increased costs on state and local governments by the FLSA. For futher elaboration of this point, see Blumstein, supra note 66, at 485-86 nn.48, 53 . 
fact no real impairment. Justice Brennan meticulously catalogued the enormous sums of money that the federal government contributes to the states-about sixty times the projected cost impact of the FLSA on state and local governments-and concluded "there is little doubt that the States' influence in the political process is adequate to safeguard their sovereignty."202

Three components can therefore be derived from Usery: first, there must be an attribute of sovereignty involved; second, the state activity must be an essential governmental function; and third, there must be an impairment of that state function. Application of these tenth amendment principles embodied in Usery to the Parker context does produce a method for distinguishing between protected and unprotected state activities. This method seems capable of allaying the Cantor dissenters' fears of freewheeling judicial decision making ${ }^{203}$ and of federal intrusion into "those areas of state regulation where the State's sovereign interest is . . . at its strongest." ${ }^{\text {"204 }}$ Moreover, as will be demonstrated below, it seems that an Usery type of analysis would not be objectionable to the Cantor plurality.

In applying the $U$ sery analysis to the Parker exemption, the first inquiry is whether a given exercise of state power is a sovereign function. As a threshold matter, the state or local government must show that a regulatory program was designed and implemented to promote an "attribute of sovereignty," that is, a legitimate police power goal. This would allow a party to show that the alleged purpose of the program was not the achievement of a public purpose but rather the promotion of private protectionism and anticompetitiveness. ${ }^{205}$

In order to prevail in this phase, a plaintiff would have the burden of presenting credible evidence that a regulation was designed or intended to promote anticompetitive objectives. If a plaintiff could show

202. 426 U.S. at 878 . Building on this argument of Justice Brennan, Professor Choper has urged that issues involving the scope of federal power under the commerce clause be declared nonjusticiable. Choper, The Scope of National Power vis-a-vis the States: The Dispensability of Judicial Review, 86 YALE L.J. 1552 (1977).

203. See text accompanying notes 178-82 supra.

204. 428 U.S. at 637.

205. This type of inquiry is suggested by the recent case of Hunt v. Washington State Apple Advertising Comm'n, 432 U.S. 333 (1977), in which the Supreme Court struck down a North Carolina statute providing that all closed containers of apples could bear no grade other than the applicable U.S. grade. While the statute seems innocuous enough on its face, it had the effect of substantially increasing the cost to Washington growers of doing business in North Carolina. This occurred because the Washington apple industry had its own very stringent grading system, which had in large part been responsible for the competitive advantage the industry had acquired. Although the Court found that the statute imposed such a burden on interstate commerce that it was unconstitutional no matter what the motivation, the Court made it clear that it questioned North Carolina's motives. Id. at 352-53. 
that this was a substantial factor in the decision to regulate or thwart competition, then it would be the defendant's burden to show by a preponderance of the evidence that the anticompetitive animus was not the causal factor in the decision making process. That is, the defendants would have an opportunity to prove that legitimate police power goals were promoted by governmental action and that the decision would have been the same even in the absence of the protectionist elements. ${ }^{206}$

If a legitimate police power goal, that is, an "attribute of sovereignty," could be demonstrated, a state regulatory scheme would be exempt from federal antitrust laws if the regulation were in furtherance of a sufficiently important-in other words, "essential"-state function. ${ }^{207}$ The Court in Usery did not precisely delineate what state activities constitute "functions essential to [the states'] separate and independent existence." 208 The opinion, however, suggested that there are two categories of sovereign functions-"administering the public law and furnishing public services" 209 and particularly noted the impact of the FLSA on the second category. The federal regulation would, the Court emphasized, displace "state policies regarding the manner in which they structure the delivery of government services their citizens require." 210 The Court set out a partial catalogue of the services it regarded as services a state could provide as part of its "sovereign" functions: "fire prevention, police protection, sanitation, public health, and parks and recreation."211 The Court noted that this was not a complete list and that the category would include all activities "within the area of traditional operations of state and local governments."212

206. This allocation of burden in proving causation tracks the Court's formulation in other areas where impermissible purpose is a factor in the analysis. See Village of Arlington Heights v. Metropolitan Housing Dev. Corp., 429 U.S. 252, 264-68 (1977); Mt. Healthy City Bd. of Educ. v. Doyle, 429 U.S. 274, 287 (1977).

207. City of Lafayette may also raise some questions concerning the extent to which a state must truly require the activity in question, at least when the party seeking immunity is a governmental entity. See note 212 infra.

208. 426 U.S. at 845 (quoting Coyle v. Oklahoma, 221 U.S. 559, 580 (1911)).

209. 426 U.S. at 851.

210. Id. at 847 .

211. Id. at 851 .

212. Id. at 851 n.16. A second aspect of determining whether a function is "sovereign" could be whether it is directed or required by the state, a point that was made clear in Goldfarb. 421 U.S. at 790-91. The decision in City of Lafayette also indicates that it is not sufficient that an activity be directed or performed by a political subdivision; the state itself must have been involved. However, this element of state direction or compulsion has distinct elements of the eleventh amendment approach discussed earlier, where the issue is who benefits from the state's Parker immunity. 
It seems likely that the Cantor plurality would not find this part of the test objectionable. The plurality was careful to point out that outlawing the light bulb program would not interfere with Michigan's regulation of public utilities. ${ }^{213}$ Apparently, the plurality would have been troubled by such interference. Similarly, the unanimous Bates decision pointed out that the "interest of the States in regulating lawyers is especially great since lawyers are essential to the primary governmental function of administering justice."214 It seems, therefore, that all of the justices recognize that there are certain governmental functions which are to be given greater deference.

The final requirement is that there be an impairment of the state's activity. As discussed above, the dissent in Usery urged that an "impairment" be evaluated with the realities of the entire situation in mind. ${ }^{215}$ The dissent argued that if a state could not afford to pay its employees the minimum wage, then in addition to the alternatives of raising taxes or cutting workers, there in fact exists a third option of getting more money from the federal government. ${ }^{216}$ This concern-that only true impairments be recognized-is reflected in the majority opinion in Cantor in which the Court stated that an exemp-

The City of Lafayette plurality reinforces the eleventh amendment nature of the inquiry by backing off somewhat from the compulsion language in Goldfarb. Justice Brennan asserted "that when the State itself has not directed or authorized an anticompetitive practice, the State's subdivisions in exercising their delegated power must obey the antitrust laws." $98 \mathrm{~S}$. Ct. 1138 (emphasis added). The dissenters strongly criticized the plurality for its very indefinite standard as to how much state involvement is necessary. Id. at 1148-50. They argued that although the plurality used the terms "authorized" and "directed" interchangeably, these terms "can have very different meanings." Id. at 1148 (citing Cantor, 428 U.S. at 492-93). Nevertheless, a careful reading of Cantor indicates some erosion of the critical nature of the distinction, since the majority there discussed authorization and command situations in terms of the faimess of holding a private party liable for obeying a command of the state. $428 \mathrm{U}$.S. at 592-95. In City of Lafayetie, the plurality's emphasis was on the degree of state involvement in the anticompetitive action of its subordinate units. This seems to be an emphasis on the eleventh amendment form of analysis. Nevertheless, evidence of a state command rather than authorization might still be seen as an element in determining whether a function is either "sovereign" or "essential."

213. 428 U.S. at 598. The "essential state function" idea is extremely prominent in both the Stevens and the Burger opinions in Cantor. For example, the Chief Justice noted that Michigan had no "independent regulatory purpose" in the utility's light bulb distribution program and that the state's "undifferentiated sanction of this ancillary practice" served no governmental policy interests. 428 U.S. at 604-05. Similarly, Justice Stevens observed that "if the federal antitrust laws should be construed to outlaw respondent's light bulb exchange program, there is no reason to believe that Michigan's regulation of its electric utilities will no longer be able to function effectively. . . . Michigan's interest in regulating its utilities' distribution of electricity will be almost entirely unimpaired." Id. at 598. For a discussion of state autonomy interests deserving of special protection, see Note, supra note 193, at 1886-88.

214. Bates v. State Bar of Ariz., 433 U.S. 350, 361-62 (1977) (quoting Goldfarb v. Virginia State Bar, 421 U.S. 773, 792 (1975)).

215. See text accompanying note 202 supra.

216. 426 U.S. at 878 . 
tion from the antitrust laws would be permitted only where it "was necessary in order to make the regulatory act work, 'and then only to the minimum extent necessary." "217 This suggests that it is not a true impairment of a state's activity to require the state to use the least restrictive alternative. When a reasonable, competitive alternative consistent with federal antitrust policy is available, then application of the federal law will not impair the state activity and neither the tenth amendment nor the Parker doctrine will exempt that activity from antitrust scrutiny.

This approach would allow a state to secure exemption from the antitrust laws in a range of activities. By demonstrating a sufficiently strong "autonomy" interest, ${ }^{218}$ a state could immunize its own regulatory programs from the coverage of existing antitrust law; that is, it could, under Parker v. Brown, secure an exemption from the preemptive effect of the federal antitrust laws. In order to achieve this result, however, the state would have to establish its autonomy or sovereignty interest in its regulatory program. ${ }^{219}$ Consistent with Cantor, this would impose a duty on the state to articulate and defend its regulatory interests and to demonstrate that it was considerate of federal interests, as well as both desirous of and justified in embarking on a different path. ${ }^{220}$ In short, this facet of the test would place a "clear statement"221 obligation on a state to assure that the decision to deviate

217. 428 U.S. at 597 (citing Otter Tail Power Co. v. United States, 410 U.S. 366, 391 (1973)).

218. See Note, supra note 193, at 1886-88.

219. State "autonomy interests" are to be identified "from both theoretical and factual inquiries into the operations of the state in the federal system . . . [I] the states are to function as a laboratory for change and a means of shaping the laws to local needs and customs, then independent and effective legislative and judicial processes are critical." $I d$. 1886. The key characteristic seems to be sustenance of "the state's role as an independent legal and political entity, which is critical to its ability to fulfill its role in a federal system." Id. 1887. This would cause careful evaluation of federal legislation that would "constrict the structural or fiscal operations of the state as to threaten the state's ability to enact and enforce its laws, maintain its governmental structure, or provide critical and necessarily public services." Id.

220. Professor S. Paul Posner has written persuasively of the need for this type of clear statement rule:

Under federalism reasoning, part of the justification for the exemption must be that,

from the vantage point of the state, other policies outweigh competition and may be

implemented with minimal injury to the interests normally secured by the competitive

process. Therefore, it makes sense to require that the choice be faced openly. . . [ []]t seems reasonable to insist that the weighing process be sufficiently explicit and overt. In addition to assuring that the weighing process assumed by the justifications is carried out, this requirement should also contribute to a reduction of the instances in which anticompetitive regulation will be enacted. If legislators have to go on record as favoring the suppression of competition, they may hesitate to do so.

Posner, supra note 21, at 715 (footnote omitted).

221. The "clear statement" language has been used in a different context to refer to an obligation on the part of Congress to articulate expressly its intent to intrude upon state interests under the eleventh or tenth amendment. For a discussion of the eleventh amendment point, see text accompanying notes 161-63 supra, L. TrIBE § 3-37; see also Note, supra note 193, at 1889. 
from federal policy was explicit, visible and done in a politically accountable manner. ${ }^{222}$ In effect, it would permit the state to thrust the ultimate responsibility for provoking a constitutional challenge on Congress itself. In order to do this, however, "at a minimum, the state should be required to face the conflict openly and squarely if state policy does clash with federal antitrust policy and is to prevail."223

If a state's claim of Parker exemption is sustained under this formulation, it remains for Congress to decide whether it wishes to push the matter further. Presumably, it could articulate explicitly that specified state activities in particular circumstances should fall within the purview of the antitrust laws. It has done this in the past in response to specific Supreme Court decisions. ${ }^{224}$ Before the ultimate tenth amendment showdown would arise, the Court would require that Congress clearly state its desire to precipitate a judicial resolution of a dispute between congressional policy and state autonomy interests in its regulatory program. ${ }^{225}$ At that point, the principles announced in Usery would be directly implicated and relied upon to determine whether Congress could displace state decision making in the relevant area.

In sum, what we have suggested is a double clear statement rule, allowing a state, in carefully delineated circumstances, to overcome the prima facie effect of the supremacy clause by an explicit, visible and accountable political decision. This would, in turn, thrust political responsibility on the federal government to respond in an explicit manner, thereby precipitating a direct test of the scope of federal authority under the commerce clause as pitted against state autonomy interests reflected in Usery.

While some may argue that the approach outlined here, building on Cantor and Usery, would result in a return to the kind of judicial activism that characterized the economic substantive due process era-an idea suggested by the Cantor dissenters ${ }^{226}$ and by Professor

222. See Posner, supra note 21 , at $715,716-17$.

223. Id. 716-17.

224. For example, the Court's decision in Schwegmann Bros. v. Calvert Distillers Corp., 341 U.S. 384 (1951), was legislatively overruled in 1952. Pub. L. No. 82-542, ch. 745, 66 Stat. 632 (repealed 1975). See Cantor, 428 U.S. at 638 n.25 (1976) (Stewart, J., dissenting). Similarly, the Court's decision in United States v. South-Eastern Underwriters Assoc., 322 U.S. 533 (1944), which held that the Sherman Act applied to the interstate insurance business, was overturned by the McCarran Act, 15 U.S.C. $\S \S 1011-1015$ (1976).

225. Professor Tribe describes the function of the clear statement rule in this context in $\mathrm{L}$. TRIBE \& 5-8. However, "notwithstanding even the clearest possible expression of congressional purpose," a federal statute can be invalid under Usery, which indeed involved a very explicit congressional attempt to supersede contrary state policy. Id. 142.

226. 428 U.S. at 627,640 . 
Verkuil ${ }^{227}$-it seems that there are significant differences in the situations that make the analogies unconvincing. ${ }^{228}$ First, the Parker $v$. Brown analysis developed here suggests the outer bounds of federal power. The concern about federal judicial supersession of state regulatory laws, comparable to the economic substantive due process cases, is unwarranted since the parallel is misplaced. If the Court holds that the Sherman Act displaces anticompetitive state regulatory policy, the states have a remedy through the legislative process-congressional modification of the Sherman Act. ${ }^{229}$ By contrast, Supreme Court invalidation of state social welfare legislation under the economic substantive due process doctrine could only be overturned by constitutional amendment. Thus, the normal concern about the Court's antimajoritarian composition is exacerbated where it second-guesses a state legislative policy, and its decision is immune from traditional political sanctions. In short, the risk of rampant activism is much greater and the stakes much higher in the economic substantive due process area than in the accommodation of federal antitrust and state regulatory policy.

Second, the Court has continued to play a more involved role in balancing federal and state policies than in reviewing state social welfare judgments. ${ }^{230}$ Even Justice Frankfurter, who was known for his advocacy of judicial self-restraint vis-a-vis state social legislation, was a proponent of greater judicial scrutiny of state policies that were inconsistent with federal policies. ${ }^{231}$ Moreover, when faced with the need for accommodating federal legislation with state regulatory policies, a decision to defer to state policy choices is necessarily a decision to countermand the policy of a coordinate branch of the federal government, a much more serious assertion of federal judicial authority. ${ }^{232}$ Unlike the due process cases, which typically did not involve a balancing of federal and state legislative authority, the Parker v. Brown context necessi-

227. Verkuil, supra note 21 , at 332-35.

228. In City of Lafayette, Justice Brennan responded to this criticism directly:

Restating a theme made and rejected before, . . . the dissent . . . likens judicial enforcement of the antitrust laws to a regime of substantive due process used by federal judges to strike down state and municipal economic regulation thought by them unfair. That analogy, of course, ignores the congressional judgment mandating broad scope in enforcement of the antitrust laws and simply refiects the dissent's view that such enforcement with respect to cities is unwise.

$98 \mathrm{~S}$. Ct. at 1138 n.46,

229. And, as Justice Brennan pointed out in his dissent in Usery, the states are well represented in Congress. 426 U.S. at 876-78. See also Choper, supra note 202.

230. See Blumstein, supra note 66 .

231. See Brown, The Open Economy: Mr. Justice Frankfurter and the Position of the Judiciary, 67 YALE L.J. 219 (1957).

232. See generally Baker v. Carr, 369 U.S. 186 (1962). 
tates judicial deference to two sets of political decision makers-federal and state. Less interventionism with respect to state policy means more potential confrontation with congressional policy judgments. Furthermore, since state interests can be heard and are represented in the federal forum, but federal or national interests are not represented in state political forums, there is every reason to defer to congressional judgments, especially given the supremacy clause. ${ }^{233}$ At a minimum, there is no special reason to yield to state policies deferentially without consideration of competing national and state interests in a balancing process. ${ }^{234}$

Third, consistent with the last point, the Court has continued to employ a federal/state balancing standard when determining whether state legislation unduly interferes with commerce under a negative commerce clause analysis. ${ }^{235}$ The existence of reasonable and adequate state alternatives which have a lesser impact on interstate commerce is by now a well accepted component of such an analysis. ${ }^{236}$ This analogy was explicitly made by Justice Blackmun in his Cantor concurrence: "Indeed, a state action that interferes with competition not only among its own citizens but also among the States is already subject under the Commerce Clause to much the same searching review of state justifications as is proposed here."237 Thus, in Southern Pacific Co. $v$. Arizona, ${ }^{238}$ the Court held invalid under the commerce clause a state restriction of train lengths because "the state [safety] interest [was] outweighed by the interest of the nation in an adequate, economical and efficient railway transportation service."239

The Court's negative commerce clause cases have developed an activist balancing approach at a time when the Court's decisions concerning economic substantive due process and equal protection have reflected extraordinary deference to state legislative policy choices. ${ }^{240}$ The justification for the different court roles is that protecting national

233. See Choper, supra note 202; Wechsler, The Political Safeguards of Federalism: The Role of the States in the Composition and Selection of the National Government, 54 CoLUM. L. REv. 543 (1954).

234. But see Usery, 426 U.S. at 841 n.12.

235. See, e.g., Raymond Motor Transport v. Rice, 98 S. Ct. 787 (1978); Great Atl. \& Pac. Tea Co. v. Cottrell, 424 U.S. 366 (1976); Pike v. Bruce Church, Inc., 397 U.S. 137 (1970).

236. See Hunt v. Washington State Apple Advertising Comm'n, 432 U.S. 333, 354 (1977);

Great Atl. \& Pac. Tea Co. v. Cottrell, 424 U.S. 366, 377 (1976); Dean Milk Co. v. Madison, 340 U.S. 349, 354 (1951). See generally Note, The Less Restrictive Alternative in Constitutional Adjudication: An Analysis, A Justification, and Some Criteria, 27 VAND. L. REv. 971, 993-95 (1974).

237. 428 U.S. at 612 (Blackmun, J., concurring).

238. 325 U.S. 761 (1945).

239. Id. at 783-84.

240. See Blumstein, supra note 66. 
as opposed to local interests is essential because of the lack of representation of national interests in state political processes, and that the risk of judicial overreaching is attenuated because of the opportunity for Congress to overturn a court decision with which it is not in sympathy. ${ }^{241}$ The same arguments apply to the Parker v. Brown situation. ${ }^{242}$

\section{State Action as an Antitrust Sword: The Case of the TIE-IN}

To this point we have considered the relationship between the antitrust laws and regulatory legislation and the special problems of federalism raised by the application of federal antitrust legislation in the state regulatory context. We have shown that the Parker v. Brown doctrine insulates certain state activity from coverage under the federal antitrust laws. In discussing Parker and its progeny, we have urged that the scope of the Parker exemption be considered in the broader context of federalism as evolved in recent tenth and eleventh amendment cases.

In the context of federalism values, Parker serves as a shield for the states against application of the federal antitrust laws, but it would be inappropriate to limit a consideration of the antitrust consequences of governmental activity to the immunity that such state action can confer. Some governmental action can actually exacerbate the antitrust susceptibility of certain private conduct. The remainder of this Article

241. See Brown, supra note 231.

242. It is also noteworthy that the tenth amendment position discussed in the text, while necessitating some federal judicial evaluation of state regulatory policies, is in fact a middle ground-more protective of the state's regulatory interest than the essentially procedural eleventh amendment approach of the Cantor plurality. The tenth amendment approach allows transfer of state immunity to private parties where necessary for the effectuation of otherwise valid state regulatory programs. The eleventh amendment approach suggested by Justice Stevens would focus exclusively on the identity of the parties and therefore result in a much more significant narrowing of the Parker exemption. Moreover, the eleventh amendment approach would likely result in circumscribing Parker immunity for sub-units of state government; however, the tenth amendment analysis explicitly includes local governments within the blanket of immunity from federal overreaching, even though they would not enjoy eleventh amendment immunity. This also suggests that the tenth amendment approach represents a middle course.

The Court's apparent division in City of Lafayette refiects the tension between the tenth and eleventh amendment approaches, the plurality suggesting that eleventh amendment cases are appropriate, the dissenters arguing that Usery is more relevant to the issues. City of Lafayette is not totally reliable, however, as an indicator of the Court's orientation because Justice White, who was in the Cantor plurality, joined the City of Lafayette dissent, while Justice Powell, who dissented in Cantor, was a member of the City of Lafayette plurality. See note 133 supra. Chief Justice Burger's concurrence in City of Lafayette seems to emphasize tenth amendment cases, and his analysis is quite similar to the approach suggested in the text. Justice Stewart in dissent noted that the Chief Justice's approach was "at once broader and narrower than the plurality's." $98 \mathrm{~S}$. Ct. at 1144 . 
will explore the antitrust implications of state action as a sword, specifically examining the effect that a governmentally conferred benefit can have in a tie-in situation.

A tie-in is an attempt by a seller to link the sale of one item to the simultaneous sale of another, separate item. There are many reasons why a seller might wish to join separate and identifiable products into a single transaction. One can plausibly look at internal subsidization, ${ }^{243}$ as practiced by many hospitals, as a form of tying arrangement. As an example, we will focus on hospital internal subsidization to illustrate the tying problem and how governmental action can increase the likelihood that an antitrust violation can be made out. Although many other illustrations of a tie-in could be used to make our point, this example is chosen in part because of its special importance in the health field and in part because of the expressed disfavor in which it is held by existing federal health planning legislation.

Internal subsidization is the practice of pricing some services above fully allocated average costs so as to generate an operating surplus which can be used to support other services that are priced below even their marginal costs of production. The major focus of our discussion will be hospital pricing and utilization decisions that implicitly reflect the implementation of substantive health policy choices by hospital policy makers. For example, a hospital may require that all laboratory tests performed for patients who use the hospital's facilities be processed by the hospital's own laboratory equipment and personnel and may then charge a higher than competitive price in order to generate sufficient excess revenues to offset losses in the infant care nursery. This classical example of internal subsidization is presumably premised on a hospital's desire to have patients who need laboratory tests assist parents of children who need special care and treatment at birth. ${ }^{244}$ The hospital then serves as the collections agent for quasi-medical charities. 245

The antitrust issue arguably raised by some forms of internal subsidization is that of a tying arrangement. If a patient who uses certain of a hospital's services must automatically use all services provided by that hospital, then there is a plausible argument for a per se violation of section 1 of the Sherman Act. ${ }^{246}$ In order to meet this standard, a plain-

243. See text accompanying notes $244-45$ infra.

244. This form of pricing has been characterized by some as "taxation by regulation." See generally Posner, Taxation by Regulation, 2 Bell J. EcoN. \& MGMT. ScI. 22 (1971).

245. See generally Kessel, Price Discrimination in Medicine, 1 J. L. \& EcoN. 20 (1958).

246. 15 U.S.C. $\S 1$ (1976). Both $\S 3$ of the Clayton Act, 15 U.S.C. $\S 14$ (1976), and $\S 1$ of the Sherman Act, 15 U.S.C. $\$ 1$ (1976), proscribe tie-in sales. The above analysis proceeds under the Sherman Act provisions because $\$ 3$ of the Clayton Act applies only to "goods, wares, merchan- 
tiff must show that the effect on commerce is "not insubstantial," 247 that the tying and tied goods are indeed separate products, ${ }^{248}$ and that the tying product has market power, that is, "some advantage not shared by . . . competitors in the market for the tying product."249

The problem can arise in a hospital context when a patient is either an inpatient or an outpatient. For example, a hospital outpatient department may require patients to have photographs included on their charts and, further, permit only official hospital-employed photographers to photograph patients for this purpose. The threshold antitrust inquiry is whether the effect on commerce of the arrangement is "not insubstantial."2so The "not insubstantial" standard is a means of eliminating de minimis claims, where the foreclosure effectuated by the tying arrangement is insignificant from a competitive viewpoint. It is clear, however, that in "determining whether the amount of commerce foreclosed is too insubstantial to warrant prohibition of the practice, ... the relevant figure is the total volume of sales tied by the sales policy under challenge, not the portion of this total accounted for by the particular plaintiff who brings suit." ${ }^{\text {251 }}$ Thus, the aggregate effect would be considered.

If a plaintiff passes the substantiality requirement, he would next confront the question whether outpatient medical services are a separate product from photography (or laboratory tests, etc.). There is ample authority to suggest that the Court will be reticent in finding them to be separate products. Times-Picayune Publishing Co. v. United

dise, machinery, supplies or other commodities." 15 U.S.C. § 14 (1976). The Sherman Act, on the other hand, has been used to challenge tie-in sales notwithstanding the absence of a tangible commodity. See United States v. Loew's, Inc., 371 U.S. 38 (1962); Northern Pac. Ry. v. United States, 356 U.S. 1 (1958). In most of the situations discussed herein, either the tying or tied product is a service, although cases involving commodities within a health care context could certainly be stated.

247. Northern Pac. Ry. v. United States, 356 U.S. 1, 6 (1958).

248. See text accompanying notes 252-62 infra.

249. United States Steel Corp. v. Fortner Enterprises, Inc. (Fortner II), 429 U.S. 610, 620 (1977).

The Clayton and Sherman Acts differ in their treatment of tying arrangements. In TimesPicayune Publishing Co. v. United States, 345 U.S. 594 (1953), the Supreme Court stated the relevant test:

When the seller enjoys a monopolistic position in the market for the "tying".product, or if a substantial volume of commerce in the "tied" product is restrained, a tying arrangement violates the narrower standard expressed in $\$ 3$ of the Clayton Act because from either factor the requisite potential lessening of competition is inferred. ... [A] tying arrangement is banned by $\$ 1$ of the Sherman Act whenever both conditions are met. Id. at 608-09 (emphasis in original).

250. Northern Pac. Ry. v. United States, 356 U.S. 1, 6 (1958).

251. Fortner Enterprises, Inc. v. United States Steel Corp. (Fortner I), 394 U.S. 495, 502 (1969). 
States $^{252}$ represents perhaps the most restrictive reading of what can constitute separate products. In that case a company owned both morning and afternoon newspapers sold in the same market. There was no competitor for the morning paper, but there was an afternoon competitor. Times-Picayune sold advertising as a package in both morning and afternoon papers; an advertiser could not purchase space in the morning paper without also buying space in that company's afternoon daily. In a 5-4 decision, the Supreme Court found that Times-Picayune was selling only a single product-advertising-not tying the purchase of space in the morning paper to the purchase of space in the afternoon paper. The Court concluded that the "record suggest[ed] that advertisers viewed the city's newspaper readers, morning or evening, as . . . fungible customer potential."253 The Court thus assumed that the readership that advertisers sought to reach was the same "product" for morning and afternoon papers. For this reason, the majority felt that no separate products existed; rather, "two newspapers under single ownership at the same place, time, and terms [sold] indistinguishable products to advertisers,"254 and therefore no "tying" product existed.

The hospital outpatient department situation could be described under Times-Picayune as a single service-medical care. But a case can be made that, unlike the advertising in Times-Picayune, the products provided-medical services and photography (or laboratory tests)-are not fungible and that separate markets readily exist in the form of competitive photography studios and independent laboratories. Moreover, Times-Picayune is probably the most restrictive case, and more recent decisions such as Fortner Enterprises, Inc. v. United States Steel Corp. ${ }^{255}$ (Fortner I) and Cantor reflect a greater willingness to differentiate among products-in Fortner $I$ between housing and credit, and in Cantor between the provision of electricity and the supplying of light bulbs. At least where an outside competitor exists and where the purpose or effect of a "tie-in" is to generate excess revenues to support other (typically inpatient) services, a plausible argument can be made for defining the services as separate products.

If outpatient medical services and photography (or other tied ancillary services) are deemed separate products affecting a "not insubstantial" amount of commerce, then United States Steel Corp. v. Fortner

252. 345 U.S. 594 (1953).

253. Id. at 613 .

254. Id. at 614.

255. 394 U.S. 495 (1969). 
Enterprises, Inc., ${ }^{256}$ (Fortner II) teaches that a plaintiff must demonstrate a provider's market power in the tying product. Justice Stevens in Fortner II noted that the cases do not require a finding that "the defendant have a monopoly or even a dominant position throughout the market for a tying product."257 Rather, the question is "whether the seller has the power within the market for the tying product, to raise prices or to require purchasers to accept burdensome terms that could not be exacted in a completely competitive market." 258

The "uniqueness" of a product or service is an important determinant of whether the seller or provider will be able to exercise market power: "Whenever there are some buyers who find a seller's product uniquely attractive, and are therefore willing to pay a premium above the price of its nearest substitute, the seller has the opportunity to impose a tie to some other good." 259 But in order for a product or service to be "unique" in this sense, it must have an element of exclusiveness-"some advantage not shared by . . competitors."260 This was stated in Fortner $I^{261}$ and reaffirmed in Fortner II: "Uniqueness confers economic power only when other competitors are in some way prevented from offering the distinctive product themselves. Such barriers may be legal, as in the case of patented and copyrighted products, . . . or physical, as when the product is land . . .."262

It is with respect to this third factor-market power-that the existence of governmental action can serve as a sword. Certificate-ofneed legislation, existing in more than two-thirds of the states ${ }^{263}$ and mandated by the federal health planning act, is designed to allocate capital facilities and equipment among potential applicants. Such certificate-of-need programs limit the ability of some providers to acquire certain equipment and therefore restrict their ability to provide some services. A facility with either equipment or facilities for which others cannot obtain a certificate will have market power of a kind that would permit an adverse antitrust finding under Fortner II.

256. 429 U.S. 610 (1977).

257. Id. at 620 .

258. Id.

259. Id. at $621 \mathrm{n} .14$ (quoting Note, The Logic of Foreclosure: Tie-In Doctrine After Fortner v. U.S. Steel, 79 YALE L.J. 86, 93-94 (1969)).

260. 429 U.S. at 620.

261. 394 U.S. at 505 n.2.

262. 429 U.S. at 621 (quoting Fortner I, 394 U.S. at 505 n.2).

263. As of January 31, 1978, thirty-six states had enacted certificate-of-need laws. Division of Regulatory Activities, Bureau of Health Planning \& Resources Development, Dep't of Health, Education \& Welfare, Status of Certificate-of-Need \& Section 1122 Programs in the States (1978). 
Thus, an outpatient facility that offered a service for which it had obtained a certificate of need-for example, a clinic with sophisticated body scanning or ultrasound diagnostic equipment-would have market power. Where a facility has received a certificate of need - thereby reducing the likelihood that competitors will be able to secure a similar piece of machinery - there is a distinct, legally enforced entry barrier that thwarts competitors from offering comparable services. This will become an especially acute problem if the proposed Carter administration hospital cost-containment program ${ }^{264}$ is enacted, since it would impose maximum dollar limits on capital expenditures. This would add teeth to the certificate-of-need program because a financial cap would absolutely restrict agency choices-either $A$ or $B$ could buy a new scanner, but not both. However, even in the absence of such financial restrictions, the certificate-of-need program is probably sufficiently analogous to the patent and copyright laws to justify a finding of uniqueness that confers market power. ${ }^{265}$ Consequently, as this brief discussion demonstrates, certain forms of state action, such as certificateof-need regulation, can have the effect of providing market power, the necessary ingredient for a finding of an antitrust violation in a tie-in situation. It seems clear after our prior discussion of Parker v. Brown that that doctrine would not now insulate the kind of private anticom-

264. See H.R. 6575, S. 1391, 95th Cong., 1st Sess. (1977).

265. See United States v. Loew's, Inc., 371 U.S. 38, 45 (1962) ("requisite economic power is presumed when the tying product is patented or copyrighted").

The antitrust issue with regard to inpatient services parallels the analysis in the outpatient context. The case for defining separate products for the various services provided to inpatients is probably weaker than with respect to outpatient services. On the other hand, the case for demonstrating market power through uniqueness is probably stronger in the inpatient than the outpatient setting.

On product separation, hospitals could argue that services provided to inpatients require coordination, that hospitals may be liable for tortious acts or omissions and therefore must be permitted to exercise operational control over the delivery of all facets of patient care, and that defining separate products in such a setting is necessarily artificial. On the other hand, just as light bulbs in Cantor were seen as sufficiently distinct from the provision of electricity to be considered separate products, one can argue plausibly that certain ancillary services are and traditionally have been provided on a basis that would readily admit of external competition. Moreover, the so-called quality control defense to tie-in allegations historically has fared poorly. See, e.g., Siegel v. Chicken Delight, Inc., 448 F.2d 43 (9th Cir. 1971), cert. denied, 405 U.S. 955 (1972). But see Dehydrating Process Co. v. A. O. Smith Corp., 292 F.2d 653 (1st Cir.), cert. denied, 368 U.S. 931 (1961).

The market power necessary to support a holding of per se illegality is probably easier to find in an inpatient than an outpatient setting. It is arguable that an inpatient hospital setting, in and of itself, represents a unique form of market power for a provider, unavailable to nonhospital competitors. It is at least plausible that, to some extent and in some circumstances, a court could be persuaded to identify and define some components of a hospital's services as sufficiently differentiated so as to permit an antitrust tying analysis. Clearly, a plausible prima facie case of tying can be made out in the case of certain hospital internal subsidization practices. 


\section{petitive conduct described here. ${ }^{266}$}

266. It is interesting to speculate about the possible intersections of Parker $v$. Brown and the tying cases that could arise in a variety of contexts. The first setting, most favorable to a finding of immunity, is that of government as provider-a state-owned and -operated hospital. Under the procedural eleventh amendment approach of the plurality in Cantor, as amplified in City of Lafayette, the question would be whether the "legislature contemplated the kind of action complained of." $98 \mathrm{~S}$. Ct. at 1138 (quoting $532 \mathrm{~F} .2 \mathrm{~d}$ at 434). That is, the inquiry would be whether the state directed or authorized the conduct involved. Although the test is not free from ambiguity, it would seem likely that a state-run facility would fall within the procedural interpretation of Parker.

Applying the more substantive tenth amendment analysis, see text accompanying notes 168242 supra, one must first determine whether the purpose for the tying arrangement is to further a policy whose promotion is an attribute of state sovereignty. Presumably, the policy of equitably redistributing the costs of hospital services among patients is a legitimate objective in this context. However, since it is an equity objective, which arguably has anticompetitive effects that otherwise would violate federal antitrust laws, we have suggested that (following Cantor and Bates) the state must make its policy choice explicit through some politically accountable body. This does not mean that broad delegations by a legislative body are impermissible, only that a specific authorization to engage in internal subsidization must be articulated. A hospital board, or state health department, could then issue regulations or guidelines outlining specific subsidization choices, acting pursuant to the legislatively delegated authority.

Provided that the internal subsidy satisfies the explicitness/political accountability criterion, it is likely that a court would find the policy to be an essential governmental function. Indeed, government's decision to provide medical services directly to a defined population is strong evidence that equity objectives-e.g., access to care-play an important role in governmental health policy making. How those services are financed in a state-run hospital would probably be perceived as closely analogous to a state taxing decision, which is clearly an essential component of a state's integrity and its ability to function within the federal system.

The final question posed by the suggested framework is whether reasonable, less anticompetitive alternatives exist by which the state can achieve its goals. This is a difficult criterion to apply to the case of government operation because the very ownership of a hospital and its use for the treatment of patients forecloses opportunities from private sector competitors; where government determines that direct provision of services is its choice of delivery mode, it is probably very unlikely that a federal court, applying antitrust principles, would or should overrule that decision.

While the government-owned and -operated hospital represents the best case for Parker $\nu$. Brown immunity in the internal subsidy situation, the role of government as financier of medical services reflects the weakest case. Here, we assume that a state-for example, through its administration of Medicaid or through a medical disability program-agrees to pay rates set by a hospital and acquiesces in its tying arrangement by reimbursing for tied services. It is questionable whether in such a circumstance the purpose could legitimately be characterized as promoting an attribute of sovereignty. Moreover, even if it were to bypass that threshold, it is distinctly unlikely that a persuasive claim could be made that the system of internal subsidy was in furtherance of an essential governmental function. It is conceivable, of course, that through its financing of care the government is pursuing redistributive policies and its expenditure of tax-raised funds would be more of a direct subsidy than in the case of the direct provision of care. To sustain that position, the government would be required, under the proposed framework, to show that a conscious, explicit and politically accountable policy choice had been made. It is not clear, after Cantor, how a mere ratification of a set of policies promulgated by a hospital could meet this standard of explicitness. Moreover, where the policy represents only approval of a hospital rate structure, the case for transferring governmental immunity to a private party would be weaker $\rightarrow$ not necessary to the effectuation of a governmentally designed regulatory policy. The alternative of direct subsidies would be readily available, would make subsidization decisions considerably more identifiable and subject to political accountability, and would be uncompli- 


\section{CONCLUSION}

The Supreme Court's 1976 decision in Cantor has added a vital and arguably novel perspective to the interface between federal law and state government regulation. We have urged that Cantor be read

cated administratively. In short, the case for Parker immunity for internal subsidies where government merely agrees to reimburse according to hospital prices and regulations is the weakest of the three under consideration.

The regulatory environment is the next context in which to consider the Parker $v$. Brown issues of hospital internal subsidization. Assume that a state regulatory agency which reviews hospital pricing and utilization policy approves the internal subsidization and tying policies of a hospital. The initial question is whether the regulatory purpose is consistent with state police power objectives-an aspect of sovereignty. Cantor and Bates would suggest that mere regulatory approval would be an insufficient showing of explicitness to warrant a firm conclusion that the decision reflects a well-considered, politically accountable decision. A purpose analysis would therefore inquire whether there were anticompetitive factors that prompted the approval of internal subsidization and, since the supporting rationale would be a principle of equity, whether there was satisfactory evidence that a conscious, explicit and politically accountable decision had been made by the state. $C f$. Board of Regents v. Bakke, $98 \mathrm{~S}$. Ct. 2733 (1978) (opinion of Powell, J.) (a governmental decision to prefer members of a racial minority in an affirmative action program must be made explicitly and by a politically accountable body in order to gain legitimacy).

If adequate support exists as to the rationale for the regulation, the issue would be whether the ability to pursue the legitimate regulatory objective is essential to the integrity of the state as a quasi-sovereign entity within the federal system. Promotion of equity goals in terms of access to medical services is likely to meet this standard. A decision to support access through a form of "taxation by regulation" would presumably be as valid as a decision to tax directly-provided the decision is taken consciously, explicitly and in a politically accountable manner. It would also seem that the state's regulatory process could only function if immunity were conferrable by the state on the regulated hospital in this case. Thus, using the essential functions test, which is derived from a tenth amendment context, one would be led to reject the limited standard suggested by the plurality in Cantor. A necessary concomitant of a viable immunity under Parker for a state regulatory apparatus is an immunity for those who act in good faith pursuant to that state policy-provided the other criteria are satisfied.

The last issue in the regulatory context is whether the state could pursue its equity goals in other ways which are less destructive of competition. This is an extremely delicate question because it involves the Court in an activist balancing stance, determining incremental benefits to the state from the state's choice of policy instruments as against the benefits to the state from an alternative means of achieving the state's goal (e.g., direct subsidy); once the incremental benefit to the state is identified, then the Court would have to balance that interest against the federal policy interest in promoting competition as a means of achieving equity and efficiency objectives. This is a style of activist judicial role that has led some commentators to advocate a narrower scope for federal antitrust policy. It is also the type of reviewing role much criticized by the dissenters in Cantor. Nevertheless, the plurality in Cantor, Justice Blackmun's concurrence in that case and even the opinion of the Chief Justice all support this type of activist stance in the Parker setting. Justice Blackmun's opinion is most explicit on this point:

We should not shrink in our general approach, however, from what seems to me our constitutionally mandated task, one often set for us by conflicting federal and state laws, and that is the balancing of implicated federal and state interests with a view to assuring that when these are truly in conflict, the former prevail.

The dissent's fears on this score appear to me to be exaggerated. The balancing of harm and benefit is, in general, a process with which federal courts are well acquainted in the antitrust field. The special problem of assessing state interests to determine whether they are strong enough to prevail against supreme federal dictates is also a familiar one to the federal courts.

428 U.S. at 611-12. 
in light of the principles and case law of the tenth and eleventh amendments to the Constitution. Eleventh amendment considerations may well be the underlying predicate of the plurality opinion in Cantor, a view that gains a measure of support from the plurality opinion in the very recent case of City of Lafayette v. Louisiana Power \& Light. ${ }^{267}$ There have been only two cases where defendants have successfully invoked the state action immunity doctrine before the Supreme Court, ${ }^{268}$ and in both situations the defendants were agencies of the state. The eleventh amendment approach would suggest a focus on the identity of the parties to a lawsuit and determinations as to whether those entities were intended by the state to secure the benefits of state immunity conferred by the eleventh amendment and whether the state, in its sovereign capacity, authorized the anticompetitive activity. ${ }^{269}$ Thus read, Parker would insulate states, their officers and other governmental entities acting pursuant to a state's explicit authorization from application of the antitrust laws. The eleventh amendment on its own already immunizes these defendants from suit for damages; Parker, under this view, would add immunity from prospective injunctive relief.

Chief Justice Burger joined in portions of the plurality opinion in Cantor, thereby making those sections holdings of a majority of the Court. The Chief Justice, and Justice Blackmun in his concurrence, rejected the portion of the plurality's opinion that seemed to be premised on the eleventh amendment. The Chief Justice and Justice Blackmun, as well as the Cantor dissenters, seemed to understand Parker as a decision grounded on principles of federalism derived from the tenth amendment. The tenth amendment influence, when coupled with the Court's decision in Usery, suggests an alternative view of Parker.

Following the Chief Justice's lead in Cantor, this approach would focus on the activities involved rather than on the parties themselves. Linking Cantor and Usery, this approach would view Parker as a doctrine designed to limit the scope of federal power under the commerce clause to impose federal economic and social policy on the states if that federal legislation would undermine state integrity or displace necessary state governmental operations in areas where the states have traditionally functioned. ${ }^{270}$ This requires that the state demonstrate

267. $98 \mathrm{~S}$. Ct. 1123 (1978). City of Lafayette was decided after this Article was written.

268. Bates v. State Bar of Ariz., 433 U.S. 350 (1977); Parker v. Brown, 317 U.S. 341 (1943).

269. See note 212 supra.

270. This is, in fact, the core of the position adopted by the Chief Justice in his concurrence in City of Lafayette. $98 \mathrm{~S}$. Ct. at 1139-43. 
that its regulatory program was designed and implemented to promote an essential governmental function and that the governmentally required anticompetitive activities be necessary to make the state regulatory system work.

This reading of Cantor seems an appropriate accommodation of antitrust and state regulatory objectives in our federal system. Considerable emphasis is accorded the supremacy clause, so that federal interests prevail over state regulatory policies except where an essential state governmental function is established which cannot be performed by less anticompetitive means. While much state regulation may fall given this new reading of state action immunity, the suggested approach, premised on a tenth amendment reading of Cantor, is significantly more protective of state regulatory interests than is the approach of the Cantor plurality. ${ }^{271}$ This reading provides an appropriate accommodation of competing interests and a judicially manageable standard that can provide an analytical framework for considering the validity of anticompetitive state conduct.

One other interesting - and perhaps surprising-conclusion of this Article is that governmental action ("state action") may in some cases exacerbate rather than minimize antitrust exposure. Thus, while the

271. Although he did not acknowledge the different doctrinal foundations for the positions of the plurality and the Chief Justice in City of Lafayette, Justice Stewart did recognize that Chief Justice Burger's approach is "at once broader and narrower than the plurality's." Id. at 1144. For Justice Stewart, the "fundamental error" of the plurality and the Chief Justice is "their failure to recognize the difference between private activities authorized or regulated by government on the one hand, and the actions of government itself on the other." Id. Justice Stewart's view is that Parker immunity attaches to governmental action; he argues that "if constitutional analogies are to be looked to" the appropriate decision is Usery rather than Edelman, which was cited by the plurality-i.e., tenth rather than eleventh amendment sources of federalism should control. Id. at 1146. The plurality's response is that Usery is not "even tangentially implicated." Id. at 1136-37 n.42. The Chief Justice, unlike the plurality, appears to accept the relevance of Usery but disagrees with the dissent by noting that Usery calls for an analysis of the nature of the governmental activities at stake. Id. at 1142-43. In short, he rejected the automatic extension of Parker immunity to municipalities-the issue in City of Lafayette-on the ground that Cantor and $U$ sery, read together, necessitated a functional analysis of the governmental activity involved. For Chief Justice Burger, "running of a business enterprise is not an integral operation in an area of traditional government functions." Id. at 1142. As he noted, Usery expressly declined to overrule the holding of United States v. California, 297 U.S. 175 (1936), which upheld federal regulation under the commerce clause of a state's operation of a common carrier. In Usery, Justice Rehnquist noted that in United Siates $v$. California the state's "activity to which the congressional command was directed was not in an area that the States have regarded as integral parts of their governmental activities." 426 U.S. at 854 n.18. Thus, while the Chief Justice appears to accept the tenth amendment approach of the dissent, he would not extend Parker immunity automatically to all governmental operations. He would require that the standards of Usery and Cantor be met. Although in a different context, the Chief Justice's approach in City of Lafayette-a case handed down after completion of this Article-has much in common with the tenth amendment approach suggested in this Article. 
Parker exemption may, under the tenth amendment approach, be extended to nongovernmental defendants who act under state compulsion in a narrow range of circumstances, state action can also be a sword rather than a shield. Because in some programs such as certificate-ofneed the state may create monopoly (or market) power, beneficiaries could find themselves susceptible to antitrust liability under a tie-in theory where they use their market power to improve their market position. If one assumes, for example, that a facility or piece of equipment that receives a certificate-of-need is sufficiently rare or unique, then a person or institution that seeks to impose utilization restrictions on access-for example, by limiting access to those who also use other, discrete services of that provider-could be subject to coverage under the antitrust laws because of the state action that, in effect, created the market power.

In sum, the Parker doctrine has gained renewed attention from the Court, which is still very much divided on the proper approach to Parker issues. What we have tried to do is develop a framework for clarifying the issues the Court must confront and propose a mode of analysis that would properly accommodate the competing federal antitrust interests and state autonomy interests. At the same time, we have shown how state involvement could become a sword as well as a shield, in some cases immunizing anticompetitive conduct from antitrust coverage, but in other situations increasing the vulnerability of those whose position has been enhanced by governmental actions. 
